\title{
Proteomic Analysis of Pancreatic Zymogen Granules: Identification of New Granule Proteins
}

\author{
Michael J. Rindler ${ }^{+}{ }^{*}$, Chong-feng Xu§, Iwona Gumper ${ }^{+}$, Nora N. Smith ${ }^{+}$, and Thomas A. \\ Neubert§ \\ +Department of Cell Biology, New York University School of Medicine, New York, NY 10016 \\ $\S$ Department of Pharmacology and Skirball Institute of Biomolecular Medicine, New York University School \\ of Medicine, New York, NY 10016
}

\begin{abstract}
The composition of zymogen granules from rat pancreas was determined by LC-MS/MS. Enriched intragranular content, peripheral membrane and integral membrane protein fractions were analyzed after one-dimensional SDS/PAGE and tryptic digestion of gel slices. A total of 371 proteins were identified with high confidence, including 84 previously identified granule proteins. The 287 remaining proteins included 37 GTP-binding proteins and effectors, 8 tetraspan membrane proteins, and 22 channels and transporters. Seven proteins - pantophysin, cyclic nucleotide phosphodiesterase, carboxypeptidase $\mathrm{D}$, ecto-nucleotide phosphodiesterase 3 , aminopeptidase $\mathrm{N}$, ral, and the potassium channel TWIK-2 - were confirmed by immunofluorescence microscopy or by immunoblotting to be new zymogen granule membrane proteins.
\end{abstract}

\section{Keywords}

proteomics; mass spectrometry; LC-MS/MS; pancreas; zymogen granules; acinar cells

\section{Introduction}

Pancreatic acinar cells are the sites of synthesis and storage of digestive enzymes released into the pancreatic duct for transport to the duodenum. ${ }^{1}$ The enzymes reside in a storage organelle in the cell cytoplasm, the zymogen granule (ZG), and are released by exocytosis into the acinar lumen. The exocytosis process involves the fusion of the ZG membranes with the apical plasma membrane and occurs after acinar cells are stimulated by hormones such as cholecystokinin and acetylcholine. Despite the relevance of the $\mathrm{ZG}$ as a mediator of digestive function, its exocytosis is only beginning to be understood at the molecular level.

Exocytosis of zymogen granules at the acinar lumen is dependent in part upon granule membrane proteins such as the SNARE (N-ethylmaleimide-sensitive factor attachment protein receptor) components syntaxin 3 and vamp $8 .{ }^{2,3}$ Recently, other proteins playing a role in exocytosis have been documented in pancreas yet were never identified as being present in ZG membranes. One such protein is Noc2, a rab-interacting protein strictly required for ZG exocytosis ${ }^{4}$ and known to be present in endocrine and salivary gland granules. ${ }^{5}$ As a postGolgi transport intermediate that can be purified in large quantities, the ZG membrane should be an abundant source of proteins involved in exocytosis and granule biogenesis in exocrine

*Address Correspondence to: Michael Rindler, Ph.D., Associate Professor, Department of Cell Biology, New York University School of Medicine, 550 First Avenue, New York, NY 10016, Tel: 212-263-5812, Fax: 212-263-8139, E-mail address: rindlm01 @ med.nyu.edu. 
pancreas. Many of these proteins are likely to be involved in similar processes in other cell types as well.

Zymogen granule membranes also contain digestive enzymes such as GP-3/pancreatic lipaserelated protein 2.6,7 Some of the membrane proteins are released into the acinar lumen and appear in the pancreatic juice. GP2, the major granule membrane protein, is anchored via a glycosylphosphatidyl inositol linkage and has both membrane and soluble forms ${ }^{8}$ as does ITMAP, a granule transmembrane protein. ${ }^{9}$ Membranes contain proteins that are thought to aid in granule formation. These include muclin, a sulfated glycoprotein in mouse pancreas; $10 \mathrm{ZG16}$, a lectin thought to help form a protein scaffold for attachment of granule content proteins to the membrane; ${ }^{11}$ and syncollin, which regulates granule size and release. ${ }^{12,13} \mathrm{ZG}$ membranes also have ion channels and transporters important for maintaining low $\mathrm{pH}$ and the ionic milieu in the granule lumen. ${ }^{14}$

The major zymogen granule content proteins have been identified previously by purification of the proteins, conventional N-terminal peptide sequencing techniques and specific immunolocalization of granule components. The granules contain hydrolytic enzymes such as amylase, the most abundant protein, trypsinogens, elastases and chymotrypsinogen. ${ }^{15}$ The importance of the granule content proteins for disease processes has been highlighted by the demonstration that individuals with mutations in trypsinogen are predisposed to pancreatitis because of the premature activation of the zymogen trypsinogen to trypsin. 16

Because of the importance of knowing the composition of the intragranular content as well as granule membrane proteins, we undertook a comprehensive identification of these proteins by LC-MS/MS. Methods for obtaining highly purified secretory granules and their membranes have been reported (summarized in 17 ). We prepared highly enriched content and membrane fractions and analyzed their protein composition. More than 500 proteins were identified in the preparation, including 371 with high confidence, of which 84 are known granule proteins. A number of these proteins potentially are important regulators of granule exocytosis. We confirmed seven of the newly identified proteins to be granule membrane proteins.

\section{Materials and Methods}

Isolation of Zymogen Granules. The purification of zymogen granules was performed as described previously in detail. ${ }^{17}$ In brief, pancreas was removed from male and female Sprague Dawley or Brown Norway rats (for preparation of content fractions only) fed ad libitum, then anesthetized using $\mathrm{CO}_{2}$ narcosis in compliance with $\mathrm{NIH}$ animal care and use guidelines and decapitated. The pancreas was washed three times in homogenization buffer (HB: $0.27 \mathrm{M}$ sucrose, $2 \mathrm{mM}$ MOPS, $0.5 \mathrm{mM} \mathrm{MgSO}_{4}, \mathrm{pH}$ 6.5-6.7). All solutions contained a protease inhibitor cocktail of $1 \mu \mathrm{g} / \mathrm{ml}$ each of leupeptin and pepstatin (Roche Applied Science, Indianapolis, IN), $10 \mathrm{U} / \mathrm{ml}$ aprotinin (Sigma-Aldrich, St. Louis, MO), and either $0.5 \mathrm{mM}$ phenylmethanesulfonyl fluoride (PMSF) or benzamidine (Sigma-Aldrich). The mesentery was trimmed from the pancreas and the tissue minced with scalpels and fine scissors. After homogenization with three strokes of a Teflon-glass homogenizer (Wheaton, Milville, NJ), a post-nuclear supernatant was prepared after centrifugation at $600 \mathrm{~g}$ for $10 \mathrm{~min}$. The pellet was rehomogenized and centrifuged again. The supernatants were combined and filtered through nylon mesh. An aliquot from the post-nuclear supernatant was saved. The granules were recovered either by centrifugation at $1750 \mathrm{~g}$ for $20 \mathrm{~min}$. (content protein preparation $1=\mathrm{C} 1$ ) or by centrifugation at $3000 \mathrm{~g}$ for $30 \mathrm{~min}$. through $5 \mathrm{ml}$ cushions of $30 \%$ and $60 \%$ Percoll (GE Healthcare, Piscataway, NJ) in gradient buffer (GB: $0.26 \mathrm{M}$ sucrose $20 \mathrm{mM}$ MOPS, $1 \mathrm{mM}$ EDTA pH 6.7) (all other preparations). Granule pellets were either washed twice in HB with $1 \mathrm{mM}$ EDTA (HBE) added to remove mitochondria and gently resuspended in HB with $1 \mathrm{mM}$ EDTA $(\mathrm{C} 1)$ or the loose granule pellets in $60 \%$ Percoll were directed resuspended in HBE. 
After homogenization (5 strokes in a Dounce homogenizer) the crude granule preparation was loaded onto 60\% Percoll in GB and spun for $35 \mathrm{~min}$. at 12,000 $\mathrm{g}$. The white granules at the bottom of the gradient were gently resuspended in HBE, homogenized in a Dounce homogenizer and loaded onto 0.6 - $2 \mathrm{M}$ sucrose gradients (10 mM MOPS, 5\% Ficoll (SigmaAldrich), $1 \mathrm{mM}$ EDTA pH 6.7). After centrifugation for $4 \mathrm{~h}$ at 100,000 $g$ using an SW41 rotor and an Optima L-90K ultracentrifuge (Beckman Coulter, Fullerton, CA), the granule band near the bottom of the tube was collected and diluted with HBE. Granules were pelleted by centrifugation at $3000 \mathrm{~g}$ for $20 \mathrm{~min}$.

After resuspension of the granule pellets in $\mathrm{HBE}$, 5-6 volumes of $0.1 \mathrm{M} \mathrm{NaHCO}_{3}, \mathrm{pH} 8.1$ were added to lyse the granules. After $45 \mathrm{~min}$. of incubation, the lysed granules were loaded onto $0.5-1.1 \mathrm{M}$ sucrose gradients in gradient buffer (GB = $10 \mathrm{mM}$ HEPES. 1 mM EDTA pH 7.0) and the gradients were centrifuged for $13 \mathrm{~h}$ at $80,000 \mathrm{~g}$. The granule content was collected from the top of the gradient and concentrated by precipitation with trichloroacetic acid (TCA). The granule membrane band was collected and diluted with GB and recovered by centrifugation at 200,000 $\mathrm{g}$ for $20 \mathrm{~min}$. using a TL100.3 rotor in a TI-100 ultracentrifuge (Beckman Coulter). The membranes were sonicated and washed 2 more times in $0.1 \mathrm{M}$ $\mathrm{NaHCO}_{3}$. Membranes from the post-nuclear supernatants and other steps in the fractionation procedure were collected and washed using the same methods.

To prepare peripheral and integral membrane fractions, the membranes were subjected to carbonate extraction as previously described. ${ }^{8}$ Membranes were sonicated in $0.1 \mathrm{M} \mathrm{NaCO}_{3}$, $\mathrm{pH} 10.8$, incubated at $4^{\circ} \mathrm{C}$ for $30 \mathrm{~min}$. and then centrifuged at 200,000 $\mathrm{g}$ as described above. The extraction was repeated a second time. Membranes recovered after centrifugation were washed in $10 \mathrm{mM}$ HEPES $1 \mathrm{mM}$ EDTA. The carbonate washes (supernatants) were combined and the proteins recovered by TCA precipitation (peripheral membrane protein fraction). All fractions were frozen and stored at $-80^{\circ} \mathrm{C}$ until use. Protein concentrations were determined using the Bradford method (Bio-Rad, Hercules, CA).

Bovine pancreatic granules were prepared by a modification of the procedure of Greene et al. ${ }^{1}$ Fresh bovine pancreas was obtained from a local slaughterhouse, minced and homogenized as described above for the preparation of rat ZGs except the HB contained $0.8 \mathrm{M}$ sucrose (HBH). Granules were isolated by centrifugation at $1000 \mathrm{~g}$ for $10 \mathrm{~min}$. This centrifugation was repeated a second time and the white granule pellets were washed to remove mitochondria then were slowly resuspended in HBH with 1 mM EDTA (HBHE) and loaded on Percoll gradients as described above except with $0.7 \mathrm{M}$ sucrose. The loose granule pellets at the bottom of the Percoll gradients were resuspended in HBHE and the granules recovered by centrifugation at $3000 \mathrm{~g}$ for $20 \mathrm{~min}$. The granule pellets were resuspended in $\mathrm{HBHE}$ and lysed with $\mathrm{NaHCO}_{3}$ as described above. The membrane and content fractions were also isolated as described above for rat pancreas.

LC-MS/MS Analysis. Four independent ZG preparations from rat pancreas were analyzed by LC-MS/MS. Proteins from two intragranular content preparations, one integral membrane and one peripheral membrane preparation were separated by SDS/PAGE on 10\% gels after heating to $100^{\circ} \mathrm{C}$. for $2 \mathrm{~min}$. in the presence of $50 \mathrm{mM}$ dithiothreitol. Fifty $\mu \mathrm{g}$ of protein was loaded on each of two adjacent lanes. Gels were fixed in $46 \%$ methanol, $7 \%$ acetic acid, and $0.1 \%$ Coomassie Blue R-250, destained in this solution without Coomassie, and stored in $1 \%$ acetic acid until use. Silver staining of parallel samples using the method of Wray et al ${ }^{18}$ was used for documentation purposes only.

Twenty to 30 contiguous slices were excised from each gel. Each slice was digested using mass spectrometry grade trypsin (Promega, Madison, WI) at 12.5 to $25.0 \mathrm{ng} / \mu \mathrm{L}$ in $25 \mathrm{mM}$ $\mathrm{NH}_{4} \mathrm{HCO}_{3}$ buffer. For the peripheral membrane and integral membrane sample, $10 \% \mathrm{AcN}$ was 
added to the digestion buffer. The resulting peptides were extracted and dried under vacuum, then resuspended in $10 \mu \mathrm{l}$ of $0.1 \%$ formic acid. Four to $6 \mu 1$ of peptide mixtures were analyzed using nanoflow LC/ESI-MS/MS. The content extracts were analyzed with a CapLC HPLC coupled directly to a QTOF Micro MS (Waters, Milford, MA) and the membrane extracts were analyzed with a nanoAcquity UPLC coupled directly to a QTOF Premier MS (Waters).

For all preparations, a C18 pre-column was used to load the sample to a $75-\mu \mathrm{m} \times 15$-cm fused silica C18 analytical column. In the case of CapLC, PepMap100 was used as the analytical column (LC Packings, Dionex, Sunnyvale, CA), whereas Atlantis columns (Waters) were used for UPLC. A gradient of 2-40\% ACN in $0.1 \%$ formic acid was delivered over 80 or $120 \mathrm{~min}$ at a flow rate of $200 \mathrm{~nL} / \mathrm{min}$ through a fused silica distal end-coated tip nano-electrospray needle (New Objective, Woburn, MA). The data acquisition involved MS survey scans and automatic data-dependent MS/MS acquisitions, which were invoked after selected ions met preset parameters of minimum signal intensity of 8 counts per second, ion charge state $2+, 3$ + , or $4+$, and appropriate retention time. Survey scans of $1 \mathrm{~s}$ were followed by MS/MS of the three most intense ions for up to $6.6 \mathrm{~s}$ each, or until 6,000 total MS/MS ion counts per precursor peptide were obtained. The raw MS data were subsequently processed using ProteinLynx software (Waters), which generated DTA or PKL files from each MS/MS spectrum, which were merged into a single file containing all spectra from all of the gel bands from a single lane (i.e. one PKL file for each granule preparation).

Protein Identification Criteria. Stringent criteria for determining whether protein matches are genuine have been previously established and applied by us to the analysis of the neuronal post-synaptic density. ${ }^{19}$ We used similar criteria in these studies. The DTA or PKL files were used to search the NCBI and Swissprot nonredundant protein databases (updated on June 7, 2006) using the Mascot search engine (Version 2.1.0, Matrix Science, Boston, MA). The search parameters included peptide mass tolerance of up to 1.5 Da, MS/MS mass tolerance of up to $0.5 \mathrm{Da}$, and variable oxidation of methionines with up to one missed tryptic cleavage allowed. The Mascot algorithm was used to determine peptide and protein expectation values. Each protein in the peptide summary report that met the probability-based Mowse threshold $[p(x)<$ 0.05 ] determined by Mascot were analyzed by a stricter set of criteria to determine the number of unique peptide matches. To pass our threshold, peptides had to have a minimum 6 residues, a Mascot probability-based score $>15$, an expectation value of $<0.5$, a precursor ion mass error of $<0.5 \mathrm{Da}$, no missed cleavages and a rank of 1 . In addition, the peptide could not appear in other proteins of higher score, and for each protein, only the highest scoring peptide (lowest expectation value) with a given amino acid sequence was considered. In general, each protein match was required to have at least two nonredundant unique peptides meeting these criteria, but not also found in other proteins identified unless they were isoforms of the same protein. Exceptions were made for proteins previously shown to be in ZGs, in pancreatic juice, or in granules of parotid gland, which are close relatives, or to be highly similar to known granule proteins. For proteins with closely related family members sharing peptides, one unique peptide and one shared peptide was considered sufficient for assignment purposes. Spectra of peptides from proteins scoring 50 or below were visually inspected to assure that the peptide assignments were reliable.

Functional annotation and organelle assignments were made using ProteinCenter (Proxeon Biosystems A/S, Odense, Denmark) together with the linked Uniprot, Genbank and Unigene (for tissue-specific mRNA expression) databases. Additional annotation was incorporated from literature searches, using the references provided in the tables in the text and Supplemental Information. Proteins localized to more than one organelle were assigned to the endoplasmic reticulum or endosomes/lysosomes categories if that was their predominant localization. Since some proteins whose predominant localization is to the plasma membrane or the Golgi 
apparatus are known to be present in secretory granules, these proteins are not listed as separate categories. Otherwise, proteins are characterized as enzymes, membrane, or secreted proteins.

Antibodies. Monoclonal antibody directed against ral was purchased from BD Pharmingen. Rabbit anti-pantophysin was a gift of Dr. Rudolf Leube, (Johannes Gutenberg University, Mainz, Germany). ${ }^{20}$ Rabbit antibody to aminopeptidase M/N was a gift of Dr. Ann Hubbard (Johns Hopkins School of Medicine, Baltimore, MD) who together with Dr. Michele Maurice (INSERM Saint-Antoine Medical Faculty, Paris, France), also provided the monoclonal antiectonucleotide phosphodiesterase 3 (ENPP3). ${ }^{20,21}$ Rabbit antibodies to carboxypeptidase D and cyclic nucleotide phosphodiesterase were gifts of Drs. Lloyd Fricker (Albert Einstein College of Medicine, Bronx, NY) and David Colman (McGill Univ., Montreal, Canada), respectively. ${ }^{22,23}$ Affinity purified antibody to TWIK-2 was provided by Dr. Anant Mhatre (NYU School of Medicine) ${ }^{24}$ Antibody to ribophorin 1 was provided by Dr. Gert Kreibich (NYU School of Medicine) ${ }^{25}$ and to endolyn-78 was a gift of Drs. Melvin Rosenfeld and David Sabatini (NYU School of Medicine). ${ }^{26}$ Antibody to ral was purchased from BD Biosciences, to mitochondrial hsp60 from Stressgen, and to amylase from Sigma. Antibody to GP2 was made by our laboratory as described previously. 8

Immunofluorescence Microscopy. Rat pancreas was cut into $2 \mathrm{~mm}$ blocks and fixed for $3 \mathrm{~h}$ in $8 \%$ paraformaldehyde in $60 \mathrm{mM}$ PIPES, $25 \mathrm{mM}$ HEPES, $2 \mathrm{mM} \mathrm{MgCl} 2,10 \mathrm{mM}$ EGTA, $\mathrm{pH}$ 6.9 (PHEM). The blocks were washed in PHEM buffer and PBS with $20 \mathrm{mM}$ glycine. The blocks were infused sequentially in PBS containing $2 \%$ and $10 \%$ gelatin and then equilibrated with $2.3 \mathrm{M}$ sucrose in PBS overnight at $4^{\circ} \mathrm{C}$. After freezing at $-80^{\circ} \mathrm{C}$, thin $(0.5 \mu)$ frozen sections were prepared on a Leica cryomicrotome (Bannockburn, IL) and bound to Superfrost Plus Gold slides (Electron Microscopic Sciences, Hatfield, PA) with silicone isolators. Sections were stored at $4^{\circ} \mathrm{C}$ in $2.3 \mathrm{M}$ sucrose in PBS until use. After washing 5 times in PBS and once in PBS with $1 \%$ nonfat milk, antibodies were applied overnight (1:250-1:1000). After washing in PBS, Alexa 488 goat anti-rabbit or mouse secondary antibodies (Molecular Probes) were applied along with Texas-red conjugated phalloidin (Molecular Probes) to label actin filaments at the luminal surface of the acinar cells. DAPI was also present in the mounting medium (Prolong Gold DAPI, Invitrogen, Carlsbad, CA) for orientation purposes. Samples were photographed on a Zeiss LSM510 confocal microscope (Carl Zeiss, Thornwood, NY). Isolated granules were prepared from the Percoll gradients, diluted in HB and allowed to settle on polylysine-coated coverslips for $1 \mathrm{~h}$ at $4^{\circ} \mathrm{C}$. They were fixed in $4 \%$ paraformaldehyde, $20 \mathrm{mM}$ HEPES, $0.3 \mathrm{M}$ sucrose for $30 \mathrm{~min}$. After washing with Hank's PBS, they were stored at $4^{\circ} \mathrm{C}$. Before use, the granules were permeabilized with $0.2 \%$ TX-100 for $1 \mathrm{~min}$. Staining was otherwise conducted as described above for pancreatic sections. Samples were photographed on a Zeiss Axiophot microscope equipped with a Hamamatsu camera (Bridgewater, NJ).

Western Blotting. Immunoblotting was performed after SDS/PAGE of membrane samples from the post-nuclear supernatants and the granules. After transfer to nitrocellulose and blocking in 5\% milk, 0.5\% Tween-20 in PBS, antibodies were applied overnight (1:2001:2000). Secondary antibodies directed against rabbit or mouse IgG and coupled to horseradish peroxidase (Jackson Immunoresearch, West Grove, PA) were used with a chemiluminescence substrate (Western Lightning Plus, Perkin Elmer, Boston, MA or ECL Advance, GE

Healthcare, Piscataway, NJ) to detect the immunoradioactivity. The film was digitally scanned and processed using Adobe Photoshop. All quantitation was performed using NIH Image software.

\section{Results}

Zymogen granules were purified from rat pancreas. Based on quantification of Coomassie Blue and silver stained polyacrylamide gels of the preparation (Figure 1A) and amylase activity 
measurements (data not shown), an increase of 4.7 fold of amylase specific activity and a similar increase in the levels of the other major granule proteins was obtained. This is comparable to the 4-4.6 fold purification previously reported by ourselves ${ }^{17}$ and others. 27 , 28 Since ZG proteins constitute as much as $30 \%$ of total acinar cell protein, our preparations are close to the theoretical limit of purity. ${ }^{29}$ The granules were substantially pure and visible contamination was minimal when the fraction was examined by electron microscopy. ${ }^{17}$

Peripheral and integral membrane protein fractions were prepared from membranes incubated with sodium carbonate. ${ }^{8}$ Although there was some overlap in the protein patterns, for the most part the major peripheral and integral membrane proteins appeared distinct (Figure 1A). Using specific antibodies to other organelles, we determined that lysosomal membrane proteins were detectable in the preparation while mitochondria and endoplasmic reticulum were not detectable in granules when compared to equal amounts of the post-nuclear supernatant (Figure 1B). The presence of lysosomes was expected since some are similar in density and size to

ZGs.

Proteins from intragranular content, peripheral membrane, and integral membrane protein fractions were separated by one-dimensional SDS/PAGE. The gels were cut into slices, the proteins digested with trypsin, and the resulting peptides were analyzed by LC/MS-MS. The resulting spectra were used to search NCBInr and Swissprot databases to identify the proteins present. From the four content and membrane preparations, a total of 371 proteins were identified with high confidence (see Methods for a discussion of criteria used in this analysis). Of these, 84 were known granule proteins (23\% of the total). The functional distribution of the proteins is depicted in graphical form in Figure 2. Another 140 proteins were identified with less confidence based on a single unique peptide match (see Supplemental Table 1 for a complete list). To verify our database search criteria, we also searched a rat NCBI real/reverse combined database using the peptide sets from each ZG preparation. Even using our low stringency criteria, these searches yielded a total of only one false protein assignment, which was based on a single peptide match, confirming the validity of our methods. Moreover, this false positive result would not have survived the filter used to establish our high confidence identifications.

Table 1 includes a list of the 23 previously known granule content proteins that we identified. Many of these proteins (e.g., amylase, trypsinogens, chymotrypsinogen, elastases) are wellcharacterized ZG proteins. Others are not necessarily granule specific but have been shown to be present in granules. Among these is protein disulfide isomerase, a protein predominantly localized to the endoplasmic reticulum but present in granules as well. ${ }^{30}$ Presumably the appearance in granules occurs when molecules occasionally escape from the endoplasmic reticulum (ER) and traverse the secretory pathway.

We also identified 61 membrane proteins previously reported to be in pancreatic zymogen granule membranes (Table 1). Here again, some are predominantly localized to granules, such as GP2, the major granule membrane protein, ${ }^{8,31}$ and ITMAP. ${ }^{9}$ GP2, ITMAP, and some of the other proteins also appear in content. Proteins predominantly localized to the apical plasma membrane, such as dipeptidase I and gamma-glutamyl transpeptidase, were identified. These proteins have also been shown to be present in granule membranes. ${ }^{32,33}$ Sixteen GTP binding proteins, both conventional G protein subunits and small ras-related GTPases, which had been previously detected in pancreatic ZGs, were also identified in our studies. The vacuolar $\mathrm{H}^{+}-$ ATPase is known to acidify organelles. ZGs are acidic and several subunits have been previously shown to be present on their membranes. ${ }^{34}$ We identified 10 of the 14 known subunits. 35 
Other secreted proteins were identified in the preparation (Table 2). These include proteins that are likely to be present in rat pancreatic ZGs. For example, trypsinogen V (via a single unique peptide) and trypsinogens 8 and 9 were identified. Given the composition of ZGs, these are likely to be granule proteins. In addition four proteins found in the pancreatic juice chymopasin, clusterin, cystatin C, and gamma-glutamyl hydrolase - are likely granule candidates. Among the other secreted enzymes identified was lipoprotein lipase, a secretory protein made in many tissues and whose mRNA is present in pancreas. ${ }^{36}$

Membrane proteins were also identified that had not previously been found in zymogen granules (Table 3). These include two proteins known to be present in parotid secretory granules -- rab26 and noc2. A number of transporters and channels were also identified. These included aquaporin-8, the potassium channel TWIK-2/KCNK6, ATPases, anion and cation channels, and amino acid transporters. In addition, GTP binding proteins, enzymes, and many other membrane proteins were identified. Some of the proteins are primarily found in other organelles, such as lysosomes, which are likely present in our ZG preparations, and the endoplasmic reticulum (Table 3 and Supplemental Tables 1 and 2 in Supporting Information). Despite the large number of proteins we identified, at least 19 proteins reported in the literature to be present in granules were not detected in our LC/MS-MS analysis (Supplemental Table 2).

Four of the new proteins in Table 3 were confirmed to be ZG proteins by immunofluorescence microscopy (Figure 3 and Figure 4). These included the membrane protein pantophysin, a tetraspan membrane protein and homolog of synaptophysin thought to be involved in vesicle trafficking. ${ }^{37}$ Pantophysin was localized to ZGs on pancreatic sections (Figure 3) and on isolated granules (Figure 4). Similarly, cyclic nucleotide phosphodiesterase (CNP) was found in granules when sections or isolated granules were stained with a specific antibody (Fig. $3 \&$ Fig. 4). Ecto-nucleotide pyrophosphatase 3 (ENPP3) was localized to the apical membrane of pancreatic acinar cells using a monoclonal antibody (Figure 3) that also labeled the regions where the granules are found and isolated granules (Figure 4). Carboxypeptidase D (CPD) is a protein known to be present in the trans Golgi network in other cell types. ${ }^{22}$ It localized primarily to regions deeper in the cell than most granules (Figure 3). Immunofluorescence labeling of isolated granules using antibodies to CPD revealed intense staining of large vesicle structures and a lower, but detectable level on some of the granules (Figure 4). This would be consistent with a scenario whereby some CPD enters immature granules from the TGN but is transported out as the granules mature.

Three additional proteins were found to be enriched in granule membrane fractions as determined by immunoblotting but had low levels of labeling by immunofluorescence microscopy (Figure 5). These included the small ras-related GTPase ral and the 2P domain $\mathrm{K}$ + channel TWIK-2 (rKCNK6), The antibody to aminopeptidase N, which is known to be an apical membrane protein in many cell types, including pancreatic duct and acinar cells, ${ }^{38}$ was observed to crossreact with rat GP2 (data not shown) and so bovine membranes were used for immunoblotting. Aminopeptidase was also enriched in the pancreatic membrane fractions as compared to total membranes from the post-nuclear supernatant (Figure 5).

\section{Discussion}

Of the 371 proteins that met our criteria for high confidence identification by mass spectrometry, 84 had been previously reported to be in secretory granules. Many of the new proteins identified are secreted proteins and proteins known or predicted to be membraneassociated (Table 2 and Table 3). There was considerable redundancy in the protein composition of the different fractions. This was expected because many of the integral 
membrane proteins are also present in the content of the granules and the major granule content proteins are thought to be present in granule membranes as well.

Most of the secretory proteins identified by us were known zymogen granule proteins. However, a few are enzymes that had been identified in pancreas or pancreatic juice but never shown previously to be in granules, including gamma-glutamyl hydrolase ${ }^{39,40}$ and chymopasin, a chymotrypsin-like enzyme. ${ }^{41}$ Cystatin $\mathrm{C}$ is a small protein $(14 \mathrm{kDa})$ made by the pancreas and also found in the pancreatic juice and in granules in endocrine glands. 42,43 For this reason, it is listed in Table 2 as a good candidate for a ZG protein although only one unique peptide was detected. Clusterin, another protein that was identified, has been localized to apical region of pancreatic acinar cells undergoing regeneration, ${ }^{44}$ which would be consistent with a ZG localization in these cells. It is reasonable to propose that a small minority of acinar cells are being renewed at any given time and therefore contain this protein in their granules. Transcobalamin 2 has been previously localized in rat pancreas where it was found primarily in pancreatic duct cells. ${ }^{45}$ However, the investigators reported "irregular" staining for transcobalamin 2 over acinar cells, which would be consistent with a low level presence in ZGs.

Several proteins associated with the apical plasma membranes of epithelial cells were identified. It has already been established that some apical plasma membrane proteins, such as dipeptidase 1 and $\gamma$-glutamyl transpeptidase, are also found in ZGs. ${ }^{32,33}$ Secretory granules are most likely the transport vehicle by which these proteins, but not all apical membrane proteins, are escorted to the plasma membrane. ${ }^{46}$ ENPP3, which we have shown to be on the apical membrane of acinar cells (Figure 3 ) and at lower levels in granules, also would be in this category as would aminopeptidase $\mathrm{N}$, which was enriched in granule membranes (Figure 5). Among the other proteins identified, aquaporin- 8 is also found at the lumen of pancreatic acinar cells 47 and was identified in our ZG proteomic analysis. 5'-nucleotidase is potentially in this category as well. 48

Very few Golgi apparatus-specific proteins were found in the preparation. Two proteins concentrated in the trans Golgi network (TGN), CPD 49 and syntaxin $16^{50}$ were identified. Another Golgi protein, MG-160, is predominantly found in the medial Golgi but as a sialoglycoprotein is likely to be present as well in the trans-Golgi where sialylation is known to occur. ${ }^{51}$ It was also identified in a proteomic analysis of adrenal chromaffin granules. ${ }^{52}$ No other proteins specific for the cis and medial portions of the Golgi apparatus were detected. Granules form at the TGN and as they pinch off, it is believed that some membrane proteins of the TGN enter them. These TGN proteins are removed from the so-called immature granules (IZG) during their maturation. ${ }^{53}$ This mechanism has been demonstrated to occur for TGN proteins, such as CPD and CALNUC (nucleobindin-1) in pituitary cells 22,54 and the cationindependent mannose-6-phosphate receptor (M6PR) in pancreatic acinar cells. ${ }^{22,55}$ Indeed, M6PR was also identified in our preparations (Table 1) as was nucleobindin-2, a close relative of CALNUC known to be secreted from cells. ${ }^{56,57}$ Since IZG's would be expected to copurify with the mature granules, it is reasonable to propose that CPD, and possibly nucleobindin-2, syntaxin 16 and MG-160 are in IZGs in acinar cells as well. This would account for the staining we observed for $\mathrm{CPD}$, which was primarily in regions near the Golgi apparatus but did show low level labeling of some granules as revealed by immunofluorescence microscopy (Figure 4).

A large cohort of ion and amino acid transporters were identified including the potassium channel protein TWIK-2/rKCNK6, a two-pore weak inward rectifying channel found in many epithelial cells. ${ }^{58}$ This protein was shown to be present in granule membranes. The only cation channel previously reported to be present in granule membranes was the ATP-sensitive potassium channel subunit Kir6.1/IRK-8, 59 which was not detected in the current study. The 
amino acid transporter Slc3a2 and its subunits (L-type amino acid transporters 1 and 2) were also found. While such amino acid transporters are generally associated with the plasma membrane, it has been shown that Slc3a1, the closest homolog, is localized in secretory granules of neurons. ${ }^{60}$ Thus Slc3a2 would be a good candidate for a ZG membrane amino acid transporter.

Small GTP binding proteins and their binding partners were found in the ZG membrane preparations. In particular, rab proteins, such as rab3 and rab27 family members are known to be regulators of secretory granule exocytosis. ${ }^{61}$ A number of small GTPases had already been shown to be in ZGs (see Table 1). Rab26 is a candidate for a new ZG membrane protein. It is expressed in pancreas and it localizes to granules in parotid gland. ${ }^{62}$ As mentioned previously, noc2, a rab-binding protein found in granule membranes of salivary gland cells, ${ }^{5}$ plays a critical role in ZG release from pancreatic acinar cells. ${ }^{3}$ It was identified by LC/MS-MS in the ZG membrane preparations as well.

In addition to the rab proteins, other proteins involved in exocytosis and vesicle trafficking were also detected. These included the SNARE proteins syntaxins 3, 6, and 7, vamps 2, 3 and 8 , and SNAPS 23 and 29, which had already been detected in zymogen granules (Table 1). Syntaxins 12 and $16 \mathrm{~b}$ were also identified, although it is not known if these are granule-specific, while syntaxins 3 and 8 , which had been reported to be in zymogen granules, were not identified (see Supplementary Table 3). Other proteins in this category but never before identified in granules included synaptotagmin-like protein 1 , which interacts with rab27 and is thought to be involved in granule exocytosis, ${ }^{63}$ and the related synaptotagmin-like protein 4 , which regulates amylase secretion in parotid cells. ${ }^{64}$ Annexin A13, part of the annexin family of calcium and phospholipid binding proteins that regulates vesicle fusion at the apical membrane of polarized epithelial cells, was also identified. ${ }^{65}$ Phosphatidylinositol lipids, including PtdIns4P, are important regulators of vesicle generation and vesicle fusion. ${ }^{66} \mathrm{We}$ identified phosphatidylinositol 4-kinase type-II beta (PtdIns 4-kinase). In chromaffin granules, PtdIns 4kinase is present on secretory granules and in neuroendocrine PC12 cells, the type II form has been shown to be present in immature granules. ${ }^{67,68}$ In addition, PtdIns 4,5-kinase regulates granule exocytosis in PC12 cells. ${ }^{69}$ Thus, PtdIns 4-kinase is a potential regulator of granule biogenesis and exocytosis in pancreatic acinar cells as well.

As was anticipated, lysosomal membrane proteins were identified in the preparation by LCMS/ MS. These included the major glycoproteins, LAMP-1 and LAMP-2. However, it should be noted that proteins primarily associated with lysosomes have been identified previously in secretory granules, including CD63 and cathepsin B, both of which were identified in this study as well. It is therefore an open question as to whether these and other proteins identified that have been in part localized to lysosomes and endosomes are present as well in pancreatic ZGs.

As shown in Supplemental Table 2, at least 19 proteins reported in the literature to be present in granules were not identified, in addition to the four subunits of the $\mathrm{H}^{+}$-ATPase that were not found, as noted above. Two of the other proteins, SPINK and hsp10 are very small $(<11$ $\mathrm{kDa}$ ). Small proteins have a limited tryptic peptide repertoire and do not fix well after SDS/ PAGE, making them more difficult to detect. Caveolin was reported to be released from acinar cells in a complex with apolipoproteins A1 and E. ${ }^{70}$ This particle is large and would be removed from the content preparations during centrifugation after granule lysis. In addition, the serglycin core protein has no internal tryptic peptides. We speculate that the other proteins such as muclin, which is a major protein in mouse ZG membranes, ${ }^{10}$ were not detected either because they are expressed at low levels in rat pancreas or because their peptides did not separate adequately from those of abundant proteins. Nevertheless, in our experiments, we did identify $79 \%$ of the $\mathrm{ZG}$ proteins that had been reported in the literature. This is comparable to the $80 \%$ coverage recently reported for the MS/MS analysis of synaptic vesicle proteins 
separated using PAGE. ${ }^{71}$ Admittedly, the criteria we used to eliminate false positives may also result in our failing to identify some new granule proteins.

In a recent study using mass spectrometry, Chen et al ${ }^{72}$ reported identifying 73 new ZG proteins (along with 28 known proteins). Importantly, myosin Vc and SNAP-29, which had not been previously reported to be present in granules, were verified by immunocytochemistry to be new granule proteins. Rap1, a granule membrane protein in parotid gland secretory granules, ${ }^{73}$ was also shown to be in ZG membranes. In addition, these investigators confirmed the localization of three proteins (rab6, rab11, and rab27B) previously identified as ZG proteins. 74-76 All of these proteins were identified in our study as well (see Table 1). Of the other 67 proteins from the Chen et al ${ }^{72}$ study, one protein had been previously identified in granules, one is no longer in the rat database, 35 were also present in our preparations, and 31 were not detected by us. In summary, we identified with high confidence more than 300 proteins in our preparations that were not reported by Chen et al. ${ }^{72}$ We confirmed the identity and location of a subset of these by immunocytochemistry and Western blotting, increasing the probability that many or most of the proteins found by us in our experiments are indeed novel zymogen granule proteins.

\section{Supplementary Material}

Refer to Web version on PubMed Central for supplementary material.

\section{Acknowledgment}

We thank Drs. David Colman, Lloyd Fricker, Ann Hubbard, Gert Kreibich, Rudolf Leube, Michele Maurice, Anant Mhatre, Melvin Rosenfeld, and David Sabatini for gifts of antibodies. This work was supported by grant DK067283 from the National Institutes of Health to M.J.R. and NIH Shared Instrumentation Grant S10 RR017990 to T.A.N.

\section{References}

1. Greene LJ, Hirs CH, Palade GE. On the protein composition of bovine pancreatic zymogen granules. J Biol Chem 1963;238:2054-2070. [PubMed: 13950163]

2. Hansen NJ, Antonin W, Edwardson JM. Identification of SNAREs involved in regulated exocytosis in the pancreatic acinar cell. J Biol Chem 1999;274:22871-22876. [PubMed: 10428873]

3. Wang CC, Ng CP, Lu L, Atlashkin V, Zhang W, Seet LF, Hong W. A role of VAMP8/endobrevin in regulated exocytosis of pancreatic acinar cells. Dev Cell 2004;7:359-371. [PubMed: 15363411]

4. Matsumoto M, Miki T, Shibasaki T, Kawaguchi M, Shinozaki H, Nio J, Saraya A, Koseki H, Miyazaki M, Iwanaga T, Seino S. Noc2 is essential in normal regulation of exocytosis in endocrine and exocrine cells. Proc Natl Acad Sci U S A 2004;101:8313-8318. [PubMed: 15159548]

5. Teramae H, Fujimoto W, Seino S, Iwanaga T. Cellular expression of Noc2, a Rab effector protein, in endocrine and exocrine tissues in the mouse. Histochem Cell Biol. 2006

6. Jennens ML, Lowe ME. Rat GP-3 is a pancreatic lipase with kinetic properties that differ from colipasedependent pancreatic lipase. J Lipid Res 1995;36:2374-2382. [PubMed: 8656075]

7. Wagner AC, Wishart MJ, Mulders SM, Blevins PM, Andrews PC, Lowe AW, Williams JA. GP-3, a newly characterized glycoprotein on the inner surface of the zymogen granule membrane, undergoes regulated secretion. J Biol Chem 1994;269:9099-9104. [PubMed: 8132647]

8. Rindler MJ, Hoops TC. The pancreatic membrane protein GP-2 localizes specifically to secretory granules and is shed into the pancreatic juice as a protein aggregate. Eur. J. Cell Biol 1990;53:154163. [PubMed: 2076702]

9. Imamura T, Asada M, Vogt SK, Rudnick DA, Lowe ME, Muglia LJ. Protection from pancreatitis by the zymogen granule membrane protein integral membrane-associated protein-1. J Biol Chem 2002;277:50725-50733. [PubMed: 12401800] 
10. De Lisle RC, Norkina O, Roach E, Ziemer D. Expression of pro-Muclin in pancreatic AR42J cells induces functional regulated secretory granules. Am J Physiol Cell Physiol 2005;289:C1169-C1178. [PubMed: 15987769]

11. Kleene R, Dartsch H, Kern HF. The secretory lectin ZG16p mediates sorting of enzyme proteins to the zymogen granule membrane in pancreatic acinar cells. Eur J Cell Biol 1999;78:79-90. [PubMed: 10099930]

12. Edwardson JM, An S, Jahn R. The secretory granule protein syncollin binds to syntaxin in a Ca2(+)sensitive manner. Cell 1997;90:325-333. [PubMed: 9244306]

13. Antonin W, Wagner M, Riedel D, Brose N, Jahn R. Loss of the zymogen granule protein syncollin affects pancreatic protein synthesis and transport but not secretion. Mol Cell Biol 2002;22:15451554. [PubMed: 11839820]

14. Thevenod F. Ion channels in secretory granules of the pancreas and their role in exocytosis and release of secretory proteins. Am J Physiol Cell Physiol 2002;283:C651-C672. [PubMed: 12176723]

15. Tartakoff A, Greene LJ, Palade GE. Studies on the guinea pig pancreas. Fractionation and partial characterization of exocrine proteins. J Biol Chem 1974;249:7420-7431. [PubMed: 4436317]

16. Whitcomb DC, Gorry MC, Preston RA, Furey W, Sossenheimer MJ, Ulrich CD, Martin SP, Gates LK Jr, Amann ST, Toskes PP, Liddle R, McGrath K, Uomo G, Post JC, Ehrlich GD. Hereditary pancreatitis is caused by a mutation in the cationic trypsinogen gene. Nat Genet 1996;14:141-145. [PubMed: 8841182]

17. Rindler, MJ. Isolation of zymogen granules from rat pancreas. In: Bonifacino, JS.; Basso, M.; Harford, JB.; Lippincott-Schwartz, J.; Yamada, KM., editors. Current Protocols in Cell Biology. Vol. 1. New York: John Wiley \& Sons, Inc.; 2006. p. 3.18.1-3.18.15.

18. Wray W, Boulikas T, Wray VP, Hancock R. Silver staining of proteins in polyacrylamide gels. Anal Biochem 1981;118:197-203. [PubMed: 6175245]

19. Jordan BA, Fernholz BD, Boussac M, Xu C, Grigorean G, Ziff EB, Neubert TA. Identification and verification of novel rodent postsynaptic density proteins. Mol Cell Proteomics 2004;3:857-871. [PubMed: 15169875]

20. Roman LM, Hubbard AL. A domain-specific marker for the hepatocyte plasma membrane: localization of leucine aminopeptidase to the bile canalicular domain. J Cell Biol 1983;96:15481558. [PubMed: 6304108]

21. Maurice M, Durand-Schneider AM, Garbarz M, Feldmann G. Characterization of rat hepatocyte plasma membrane domains by monoclonal antibodies. Eur J Cell Biol 1985;39:122-129. [PubMed: 2417841]

22. Varlamov O, Eng FJ, Novikova EG, Fricker LD. Localization of metallocarboxypeptidase D in AtT-20 cells. Potential role in prohormone processing. J Biol Chem 1999;274:14759-14767. [PubMed: 10329672]

23. Trapp BD, Bernier L, Andrews SB, Colman DR. Cellular and subcellular distribution of 2',3'-cyclic nucleotide 3'-phosphodiesterase and its mRNA in the rat central nervous system. J Neurochem 1988;51:859-868. [PubMed: 2842456]

24. Mhatre AN, Li J, Chen AF, Yost CS, Smith RJ, Kindler CH, Lalwani AK. Genomic structure, cochlear expression, and mutation screening of KCNK6, a candidate gene for DFNA4. J Neurosci Res 2004;75:25-31. [PubMed: 14689445]

25. Kreibich G, Ulrich BL, Sabatini DD. Proteins of rough microsomal membranes related to ribosome binding. I. Identification of ribophorins I and II, membrane proteins characteristics of rough microsomes. J Cell Biol 1978;77:464-487. [PubMed: 649658]

26. Croze E, Ivanov IE, Kreibich G, Adesnik M, Sabatini DD, Rosenfeld MG. Endolyn-78, a membrane glycoprotein present in morphologically diverse components of the endosomal and lysosomal compartments: implications for lysosome biogenesis. J Cell Biol 1989;108:1597-1613. [PubMed: 2654137]

27. Paquet MR, St-Jean P, Roberge M, Beaudoin AR. Isolation of zymogen granules from rat pancreas and characterization of their membrane proteins. Eur J Cell Biol 1982;28:20-26. [PubMed: 6290220]

28. Cameron RS, Cameron PL, Castle JD. A common spectrum of polypeptides occurs in secretion granule membranes of different exocrine glands. J Cell Biol 1986;103:1299-1313. [PubMed: 3533952] 
29. Meldolesi J. Membranes of pancreatic zymogen granules. Methods Enzymol 1983;98:67-75. [PubMed: 6669071]

30. Bruneau N, Lombardo D, Levy E, Bendayan M. Roles of molecular chaperones in pancreatic secretion and their involvement in intestinal absorption. Microsc Res Tech 2000;49:329-345. [PubMed: 10820517]

31. Ronzio RA, Kronquist KE, Lewis DS, MacDonald RJ, Mohrlok SH, O'Donnell JJ Jr. Glycoprotein synthesis in the adult rat pancreas. IV. Subcellular distribution of membrane glycoproteins. Biochim Biophys Acta 1978;508:65-84. [PubMed: 629968]

32. Beaudoin AR, Grondin G, Laperche Y. Immunocytochemical localization of gammaglutamyltranspeptidase, GP-2 and amylase in the rat exocrine pancreas: the concept of zymogen granule membrane recycling after exocytosis. J Histochem Cytochem 1993;41:225-233. [PubMed: 7678269]

33. Hooper NM, Cook S, Laine J, Lebel D. Identification of membrane dipeptidase as a major glycosylphosphatidylinositol-anchored protein of the pancreatic zymogen granule membrane, and evidence for its release by phospholipase A. Biochem J 1997;324:151-157. [PubMed: 9164851]

34. Roussa E, Shmukler BE, Wilhelm S, Casula S, Stuart-Tilley AK, Thevenod F, Alper SL. Immunolocalization of potassium-chloride cotransporter polypeptides in rat exocrine glands. Histochem Cell Biol 2002;117:335-344. [PubMed: 11976906]

35. Beyenbach KW, Wieczorek H. The V-type H+ ATPase: molecular structure and function, physiological roles and regulation. J Exp Biol 2006;209:577-589. [PubMed: 16449553]

36. Ben-Zeev O, Doolittle MH, Davis RC, Elovson J, Schotz MC. Maturation of lipoprotein lipase. Expression of full catalytic activity requires glucose trimming but not translocation to the cis-Golgi compartment. J Biol Chem 1992;267:6219-6227. [PubMed: 1556130]

37. Haass NK, Kartenbeck MA, Leube RE. Pantophysin is a ubiquitously expressed synaptophysin homologue and defines constitutive transport vesicles. J Cell Biol 1996;134:731-746. [PubMed: 8707851]

38. Gorvel JP, Rigal A, Sarles J, Maroux S. Aminopeptidase N- and human blood group A-antigenicity along the digestive tract and associated glands in the rabbit. Cell Tissue Res 1985;239:241-248. [PubMed: 2857112]

39. Bhandari SD, Gregory JF 3rd, Renuart DR, Merritt AM. Properties of pteroylpolyglutamate hydrolase in pancreatic juice of the pig. J Nutr 1990;120:467-475. [PubMed: 2341911]

40. Kesavan V, Noronha JM. Folate malabsorption in aged rats related to low levels of pancreatic folyl conjugase. Am J Clin Nutr 1983;37:262-267. [PubMed: 6218750]

41. Sogame Y, Kataoka K, Kato M, Sakagami J, Osawa S, Takatera A, Mitsuyoshi M, Usui N, Mitsui S, Yamaguchi N. Molecular cloning and characterization of chymopasin, a novel serine protease from rat pancreas. Pancreas 2002;25:378-386. [PubMed: 12409833]

42. Gronborg M, Bunkenborg J, Kristiansen TZ, Jensen ON, Yeo CJ, Hruban RH, Maitra A, Goggins MG, Pandey A. Comprehensive proteomic analysis of human pancreatic juice. J Proteome Res 2004;3:1042-1055. [PubMed: 15473694]

43. Moller CA, Lofberg H, Grubb AO, Olsson SO, Davies ME, Barrett AJ. Distribution of cystatin C (gamma-trace), an inhibitor of lysosomal cysteine proteinases, in the anterior lobe of simian and human pituitary glands. Neuroendocrinology 1985;41:400-404. [PubMed: 2997651]

44. Min BH, Jeong SY, Kang SW, Crabo BG, Foster DN, Chun BG, Bendayan M, Park IS. Transient expression of clusterin (sulfated glycoprotein-2) during development of rat pancreas. J Endocrinol 1998;158:43-52. [PubMed: 9713325]

45. Lee EY, Seetharam B, Alpers DH, DeSchryver-Kecskemeti K. Immunohistochemical survey of cobalamin-binding proteins. Gastroenterology 1989;97:1171-1180. [PubMed: 2676682]

46. Colomer V, Rindler MJ, Lowe AL. Apical plasma membrane proteins of exocrine cells do not obligatorily transit through secretory granules en route to the cell surface. J. Cell Science 1994;107:2271-2277. [PubMed: 7983185]

47. Tani T, Koyama Y, Nihei K, Hatakeyama S, Ohshiro K, Yoshida Y, Yaoita E, Sakai Y, Hatakeyama $\mathrm{K}$, Yamamoto T. Immunolocalization of aquaporin-8 in rat digestive organs and testis. Arch Histol Cytol 2001;64:159-168. [PubMed: 11436986] 
48. Uchiyama Y. A histochemical study of variations in the localization of 5'-nucleotidase activity in the acinar cell of the rat exocrine pancreas over the twenty-four hour period. Cell Tissue Res 1983;230:411-420. [PubMed: 6303596]

49. Varlamov O, Fricker LD. Intracellular trafficking of metallocarboxypeptidase D in AtT-20 cells: localization to the trans-Golgi network and recycling from the cell surface. J Cell Sci 1998;111(Pt 7):877-885. [PubMed: 9490632]

50. Mallard F, Tang BL, Galli T, Tenza D, Saint-Pol A, Yue X, Antony C, Hong W, Goud B, Johannes L. Early/recycling endosomes-to-TGN transport involves two SNARE complexes and a Rab6 isoform. J Cell Biol 2002;156:653-664. [PubMed: 11839770]

51. Gonatas JO, Mezitis SG, Stieber A, Fleischer B, Gonatas NK. MG-160. A novel sialoglycoprotein of the medial cisternae of the Golgi apparatus [published eeratum appears in J Biol Chem 1989 Mar 5;264(7):4264]. J Biol Chem 1989;264:646-653. [PubMed: 2909545]

52. Wegrzyn J, Lee J, Neveu JM, Lane WS, Hook V. Proteomics of Neuroendocrine Secretory Vesicles Reveal Distinct Functional Systems for Biosynthesis and Exocytosis of Peptide Hormones and Neurotransmitters. J Proteome Res. 2007

53. Arvan P, Castle D. Sorting and storage during secretory granule biogenesis: looking backward and looking forward. Biochem J 1998;332(Pt 3):593-610. [PubMed: 9620860]

54. Lavoie C, Meerloo T, Lin P, Farquhar MG. Calnuc, an EF-hand $\mathrm{Ca}(2+)$-binding protein, is stored and processed in the Golgi and secreted by the constitutive-like pathway in AtT20 cells. Mol Endocrinol 2002;16:2462-2474. [PubMed: 12403836]

55. Klumperman J, Kuliawat R, Griffith JM, Geuze HJ, Arvan P. Mannose 6-phosphate receptors are sorted from immature secretory granules via adaptor protein AP-1, clathrin, and syntaxin 6-positive vesicles. J Cell Biol 1998;141:359-371. [PubMed: 9548715]

56. Islam A, Adamik B, Hawari FI, Ma G, Rouhani FN, Zhang J, Levine SJ. Extracellular TNFR1 release requires the calcium-dependent formation of a nucleobindin 2-ARTS-1 complex. J Biol Chem 2006;281:6860-6873. [PubMed: 16407280]

57. Oh IS, Shimizu H, Satoh T, Okada S, Adachi S, Inoue K, Eguchi H, Yamamoto M, Imaki T, Hashimoto K, Tsuchiya T, Monden T, Horiguchi K, Yamada M, Mori M. Identification of nesfatin-1 as a satiety molecule in the hypothalamus. Nature 2006;443:709-712. [PubMed: 17036007]

58. Lesage F, Lazdunski M. Molecular and functional properties of two-pore-domain potassium channels. Am J Physiol Renal Physiol 2000;279:F793-F801. [PubMed: 11053038]

59. Abu-Hamdah R, Cho WJ, Cho SJ, Jeremic A, Kelly M, Ilie AE, Jena BP. Regulation of the water channel aquaporin-1: isolation and reconstitution of the regulatory complex. Cell Biol Int 2004;28:717. [PubMed: 14759764]

60. Nirenberg MJ, Tate SS, Mosckovitz R, Udenfriend S, Pickel VM. Immunocytochemical localization of the renal neutral and basic amino acid transporter in rat adrenal gland, brainstem, and spinal cord. J Comp Neurol 1995;356:505-522. [PubMed: 7560263]

61. Seabra MC, Mules EH, Hume AN. Rab GTPases, intracellular traffic and disease. Trends Mol Med 2002;8:23-30. [PubMed: 11796263]

62. Yoshie S, Imai A, Nashida T, Shimomura H. Expression, characterization, and localization of Rab26, a low molecular weight GTP-binding protein, in the rat parotid gland. Histochem Cell Biol 2000;113:259-263. [PubMed: 10857477]

63. Fukuda M. Rab27 and its effectors in secretory granule exocytosis: a novel docking machinery composed of a Rab27.effector complex. Biochem Soc Trans 2006;34:691-695. [PubMed: 17052176]

64. Fukuda M, Imai A, Nashida T, Shimomura H. Slp4-a/granuphilin-a interacts with syntaxin-2/3 in a Munc18-2-dependent manner. J Biol Chem 2005;280:39175-39184. [PubMed: 16186111]

65. Lafont F, Lecat S, Verkade P, Simons K. Annexin XIIIb associates with lipid microdomains to function in apical delivery. J Cell Biol 1998;142:1413-1427. [PubMed: 9744874]

66. De Matteis MA, Godi A. PI-loting membrane traffic. Nat Cell Biol 2004;6:487-492. [PubMed: 15170460]

67. Panaretou C, Tooze SA. Regulation and recruitment of phosphatidylinositol 4-kinase on immature secretory granules is independent of ADP-ribosylation factor 1. Biochem J 2002;363:289-295. [PubMed: 11931656] 
68. Wiedemann C, Schafer T, Burger MM. Chromaffin granule-associated phosphatidylinositol 4-kinase activity is required for stimulated secretion. Embo J 1996;15:2094-2101. [PubMed: 8641275]

69. Aikawa Y, Martin TF. ARF6 regulates a plasma membrane pool of phosphatidylinositol $(4,5)$ bisphosphate required for regulated exocytosis. J Cell Biol 2003;162:647-659. [PubMed: 12925709]

70. Liu P, Li WP, Machleidt T, Anderson RG. Identification of caveolin-1 in lipoprotein particles secreted by exocrine cells. Nat Cell Biol 1999;1:369-375. [PubMed: 10559965]

71. Takamori S, Holt M, Stenius K, Lemke EA, Gronborg M, Riedel D, Urlaub H, Schenck S, Brugger B, Ringler P, Muller SA, Rammner B, Grater F, Hub JS, De Groot BL, Mieskes G, Moriyama Y, Klingauf J, Grubmuller H, Heuser J, Wieland F, Jahn R. Molecular anatomy of a trafficking organelle. Cell 2006;127:831-846. [PubMed: 17110340]

72. Chen X, Walker AK, Strahler JR, Simon ES, Tomanicek-Volk SL, Nelson BB, Hurley MC, Ernst SA, Williams JA, Andrews PC. Organellar proteomics: analysis of pancreatic zymogen granule membranes. Mol Cell Proteomics 2006;5:306-312. [PubMed: 16278343]

73. D'Silva NJ, DiJulio DH, Belton CM, Jacobson KL, Watson EL. Immunolocalization of rap1 in the rat parotid gland: detection on secretory granule membranes. J Histochem Cytochem 1997;45:965973. [PubMed: 9212822]

74. Iida H, Tanaka S, Shibata Y. Small GTP-binding protein, Rab6, is associated with secretory granules in atrial myocytes. Am J Physiol 1997;272:C1594-C1601. [PubMed: 9176151]

75. Hori Y, Takeyama Y, Hiroyoshi M, Ueda T, Maeda A, Ohyanagi H, Saitoh Y, Kaibuchi K, Takai Y. Possible involvement of Rab11 p24, a Ras-like small GTP-binding protein, in intracellular vesicular transport of isolated pancreatic acini. Dig Dis Sci 1996;41:133-138. [PubMed: 8565746]

76. Chen X, Li C, Izumi T, Ernst SA, Andrews PC, Williams JA. Rab27b localizes to zymogen granules and regulates pancreatic acinar exocytosis. Biochem Biophys Res Commun 2004;323:1157-1162. [PubMed: 15451418]

77. Tooze J, Hollinshead M, Hensel G, Kern HF, Hoflack B. Regulated secretion of mature cathepsin B from rat exocrine pancreatic cells. Eur J Cell Biol 1991;56:187-200. [PubMed: 1802707]

78. Lechene de la Porte P, Amouric M, Figarella C. Immunolocalization of kallikrein in porcine pancreas at the ultrastructural level. Hoppe Seylers Z Physiol Chem 1981;362:439-443. [PubMed: 6909109]

79. Wang S, Lukinius A, Zhou Y, Stalberg P, Gobl A, Oberg K, Skogseid B. Subcellular distribution of phospholipase $\mathrm{C}$ isoforms in rodent pancreas and gastric mucosa. Endocrinology 2000;141:25892593. [PubMed: 10875262]

80. Lechene de la Porte P, de Caro A, Lafont H, Sarles H. Immunocytochemical localization of pancreatic stone protein in the human digestive tract. Pancreas 1986;1:301-308. [PubMed: 3550781]

81. Bendayan M. Ultrastructural localization of cytoskeletal proteins in pancreatic secretory cells. Can J Biochem Cell Biol 1985;63:680-690. [PubMed: 2412674]

82. Massey-Harroche D, Mayran N, Maroux S. Polarized localizations of annexins I, II, VI and XIII in epithelial cells of intestinal, hepatic and pancreatic tissues. J Cell Sci 1998;111(Pt 20):3007-3015. [PubMed: 9739074]

83. Fukuoka S, Kern H, Kazuki-Sugino R, Ikeda Y. Cloning and characterization of ZAP36, an annexinlike, zymogen granule membrane associated protein, in exocrine pancreas. Biochim Biophys Acta 2002;1575:148-152. [PubMed: 12020832]

84. Hatskelzon L, Dalal BI, Shalev A, Robertson C, Gerrard JM. Wide distribution of granulophysin epitopes in granules of human tissues. Lab Invest 1993;68:509-519. [PubMed: 7684475]

85. Kelly ML, Abu-Hamdah R, Jeremic A, Cho SJ, Ilie AE, Jena BP. Patch clamped single pancreatic zymogen granules: direct measurements of ion channel activities at the granule membrane. Pancreatology 2005;5:443-449. [PubMed: 15985770]

86. Braun JE, Scheller RH. Cysteine string protein, a DnaJ family member, is present on diverse secretory vesicles. Neuropharmacology 1995;34:1361-1369. [PubMed: 8606785]

87. Kraemer J, Schmitz F, Drenckhahn D. Cytoplasmic dynein and dynactin as likely candidates for microtubule-dependent apical targeting of pancreatic zymogen granules. Eur J Cell Biol 1999;78:265-277. [PubMed: 10350215]

88. Poucell-Hatton S, Perkins PS, Deerinck TJ, Ellisman MH, Hardison WG, Pandol SJ. Myosin I is associated with zymogen granule membranes in the rat pancreatic acinar cell. Gastroenterology 1997;113:649-658. [PubMed: 9247487] 
89. Wishart MJ, Andrews PC, Nichols R, Blevins GT Jr, Logsdon CD, Williams JA. Identification and cloning of GP-3 from rat pancreatic acinar zymogen granules as a glycosylated membrane-associated lipase. J Biol Chem 1993;268:10303-10311. [PubMed: 8486693]

90. von Zastrow M, Tritton TR, Castle JD. Exocrine secretion granules contain peptide amidation activity. Proc Natl Acad Sci U S A 1986;83:3297-3301. [PubMed: 3458183]

91. Brand SH, Laurie SM, Mixon MB, Castle JD. Secretory carrier membrane proteins 31-35 define a common protein composition among secretory carrier membranes. J Biol Chem 1991;266:18949_ 18957. [PubMed: 1717458]

92. Blum R, Feick P, Puype M, Vandekerckhove J, Klengel R, Nastainczyk W, Schulz I. Tmp21 and p24A, two type I proteins enriched in pancreatic microsomal membranes, are members of a protein family involved in vesicular trafficking. J Biol Chem 1996;271:17183-17189. [PubMed: 8663407]

93. Gaisano HY, Sheu L, Grondin G, Ghai M, Bouquillon A, Lowe A, Beaudoin A, Trimble WS. The vesicle-associated membrane protein family of proteins in rat pancreatic and parotid acinar cells. Gastroenterology 1996;111:1661-1669. [PubMed: 8942747]

94. Shimada O, Hara-Kuge S, Yamashita K, Tosaka-Shimada H, Yanchao L, Einan L, Atsumi S, Ishikawa H. Localization of VIP36 in the post-Golgi secretory pathway also of rat parotid acinar cells. J Histochem Cytochem 2003;51:1057-1063. [PubMed: 12871987]

95. Cronshagen U, Voland P, Kern HF. cDNA cloning and characterization of a novel $16 \mathrm{kDa}$ protein located in zymogen granules of rat pancreas and goblet cells of the gut. Eur J Cell Biol 1994;65:366377. [PubMed: 7720729]

96. Chen CY, Cronshagen U, Kern HF. A novel pancreas-specific serpin (ZG-46p) localizes to the soluble and membrane fraction of the Golgi complex and the zymogen granules of acinar cells. Eur J Cell Biol 1997;73:205-214. [PubMed: 9243181]

97. Padfield PJ, Panesar N. Identification of Goalpha, Gqalpha, and Gsalpha immunoreactivity associated with the rat pancreatic zymogen granule membrane. Biochem Biophys Res Commun 1997;237:235238. [PubMed: 9268692]

98. Sattar AA, Boinpally R, Stromer MH, Jena BP. G(alpha)(i3) in pancreatic zymogen granules participates in vesicular fusion. J Biochem (Tokyo) 2002;131:815-820. [PubMed: 12038977]

99. Ohnishi H, Ernst SA, Yule DI, Baker CW, Williams JA. Heterotrimeric G-protein Gq/11 localized on pancreatic zymogen granules is involved in calcium-regulated amylase secretion. J Biol Chem 1997;272:16056-16061. [PubMed: 9188511]

100. Valentijn JA, Sengupta D, Gumkowski FD, Tang LH, Konieczko EM, Jamieson JD. Rab3D localizes to secretory granules in rat pancreatic acinar cells. Eur J Cell Biol 1996;70:33-41. [PubMed: 8738417]

101. Wagner AC, Strowski MZ, Williams JA. Identification of Rab 5 but not Rab 3A in rat pancreatic zymogen granule membranes. Biochem Biophys Res Commun 1994;200:542-548. [PubMed: 8166729]

102. Roussa E, Alper SL, Thevenod F. Immunolocalization of anion exchanger $\mathrm{AE} 2, \mathrm{Na}(+) / \mathrm{H}(+)$ exchangers NHE1 and NHE4, and vacuolar type $\mathrm{H}(+)$-ATPase in rat pancreas. J Histochem Cytochem 2001;49:463-474. [PubMed: 11259449] 


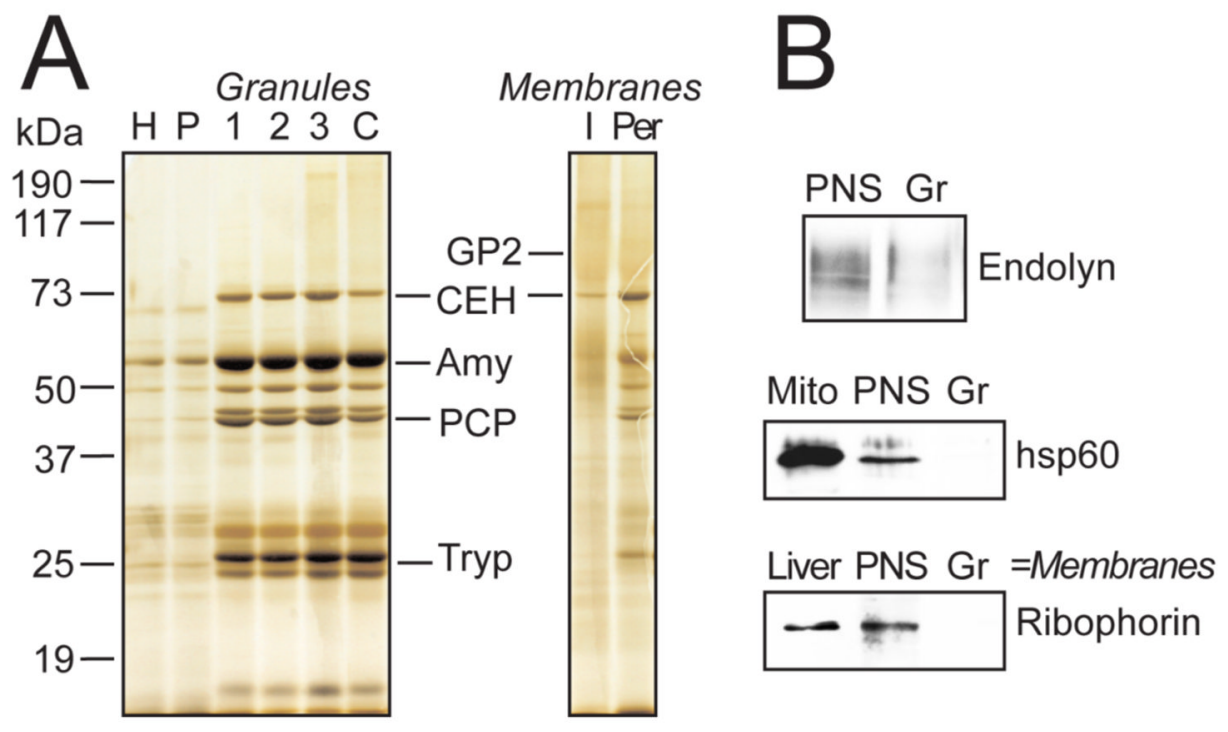

Figure 1.

Preparation of zymogen granules from rat pancreas. A) Granules were prepared as described in the Methods. $5 \mu \mathrm{g}$ of the initial homogenate $(\mathrm{H})$, the post-nuclear supernatant (PNS), the first granule pellet (1), the Percoll gradient fraction (2), and the final purified granules recovered from the sucrose gradient (3) were subjected to SDS/PAGE on 10\% gels. The granule content fraction (C) as well as the integral (I) and peripheral (Per) membrane fractions isolated after treatment of the membranes with $0.1 \mathrm{M}$ sodium carbonate are also depicted. Amylase and other content protein bands were enriched $\sim 5$ fold. B) $5 \mu \mathrm{g}$ of protein from the indicated fractions was used in immunoblotting experiments after SDS/PAGE and transfer to nitrocellulose. Antibodies specific for the endosome/lyososome membrane marker endolyn, the mitochondrial protein hsp60 and the endoplasmic reticulum membrane protein ribophorin 1 were used as probes and the blots developed using the enhanced chemiluminescence method. Anti-endolyn samples were membranes from the homogenate, PNS, and granule fractions. Anti-hsp60 samples were a mitochondrial fraction prepared from rat pancreas (Mito.), PNS and purified granules (Gr). Anti-ribophorin samples consisted of total rat liver membranes, pancreas PNS membranes, and granule membranes. The data show that lysosomes are present in the granule preparation but not enriched while mitochondria and endoplasmic reticulum were not detected by this method, indicating that they were selectively depleted during zymogen granule purification. The intensity of the bands using these methods was linear over $\sim 8$ fold range (not shown). 


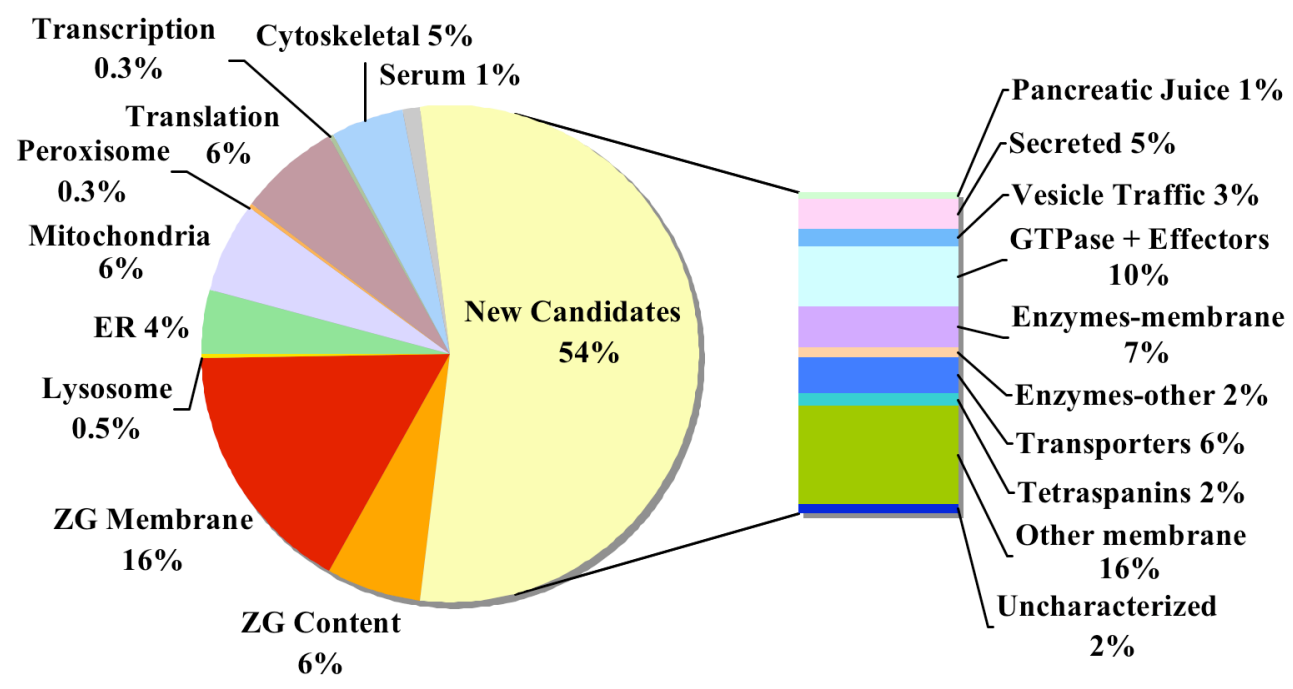

Figure 2.

Diagram of the functional categories of the soluble and membrane proteins identified by LCMS/MS. Based on annotations in the ProteinCenter, Uniprot and Genbank databases or predictions based on similarity to related proteins in the same databases, the 371 proteins identified with high confidence (see text) are grouped in the pie chart according to their functional and subcellular distribution. 23\% were known zymogen granule proteins and $54 \%$ were candidates for new granule proteins. At right, the new candidates are broken out by category together with the percent of the total proteins identified (as listed in Table 3; also see Supplemental Table 2 for detailed annotation). 

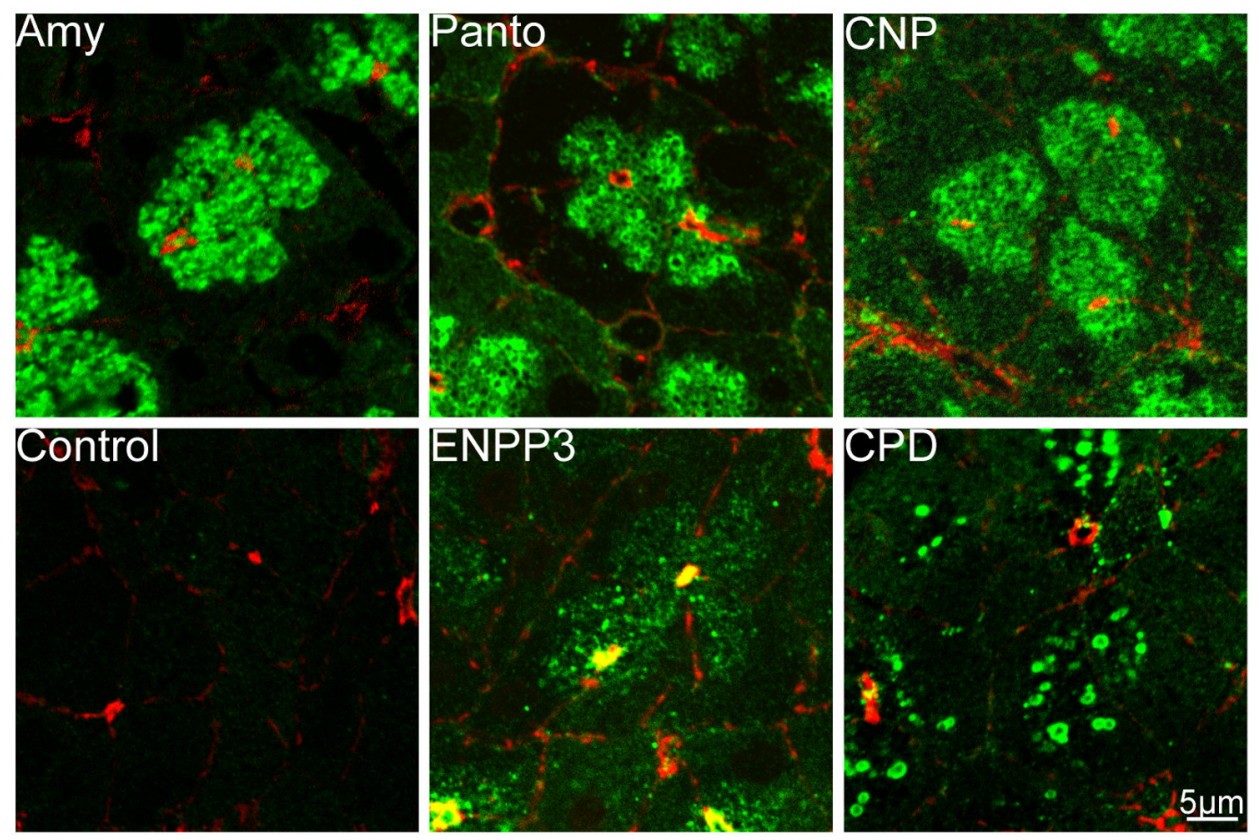

Figure 3.

Immunofluorescence microscopy of pancreatic sections. Frozen thin sections of rat pancreas were incubated with rabbit antibodies to amylase (Amy), pantophysin (Panto),

carboxypeptidase D (CPD), and cyclic nucleotide phosphodiesterase (CNP) as well as a monoclonal antibody to ecto-nucleoside pyrophosphatase 3 (ENPP3). The negative control was a nonimmune rabbit serum used at the same dilution (1:200). Controls performed using irrelevant mouse monoclonal antibodies gave even lower nonspecific background (data not shown). Alexa 488 - conjugated anti-mouse or anti-rabbit IgG was used in a second step along with TX-Red conjugated phalloidin, which binds strongly to actin at the acinar lumen. Pantophysin and CNP labeling was over the granule region and to some extent over other membranes of the cell. CPD labeling was primarily in regions deeper than the bulk of the granules and is consistent with its presence in the trans Golgi network. ENPP3 was localized predominantly over the lumenal membranes of the acinar cells but also at a low level over the granule region beneath it. By comparison, amylase labeling, as expected, was over the ZG's surrounding the acinar lumens. 

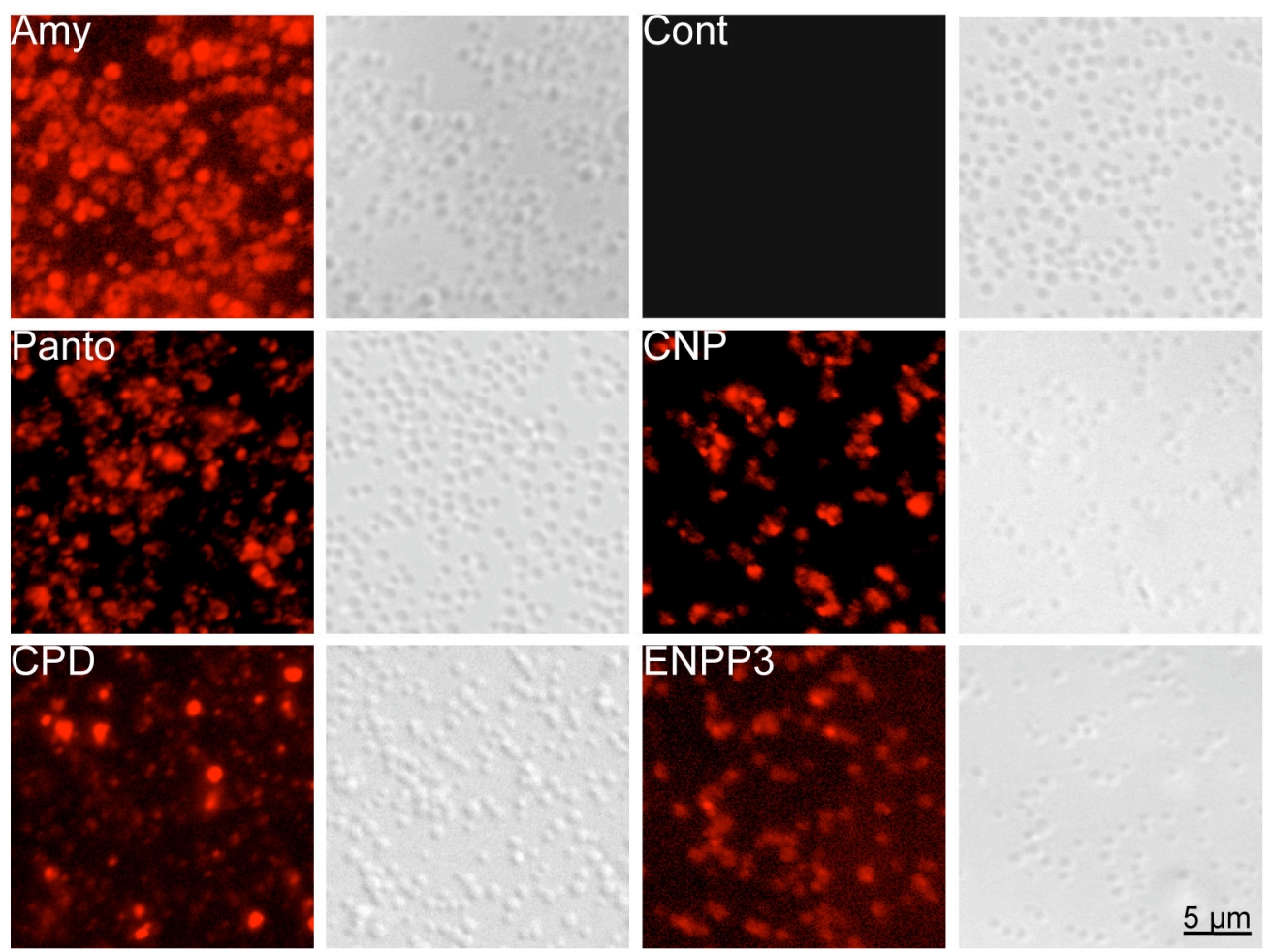

Figure 4.

Immunofluorescence microscopy on isolated granules. Zymogen granules on coverslips were stained for immunofluorescence microscopy using antibodies against amylase (Amy), pantophysin (Panto), CPD, CNP, and ENPP3. Rhodamine-conjugated anti-mouse or antirabbit IgG was used in a second step. Depicted in parallel are representative fields using fluorescent and differential interference contrast filters. All of the antibodies gave specific signal although anti-CPD labeled some large vesicles very intensely with low level labeling over the bulk. ENPP3 staining was weak compared to pantophysin or CNP, as expected (see Figure 3). Control coverslips were incubated in a nonimmune rabbit serum and rhodamineconjugated anti-rabbit IgG. They were photographed at the longest exposure used for the antibody-stained coverslips and processed similarly using Adobe Photoshop. 

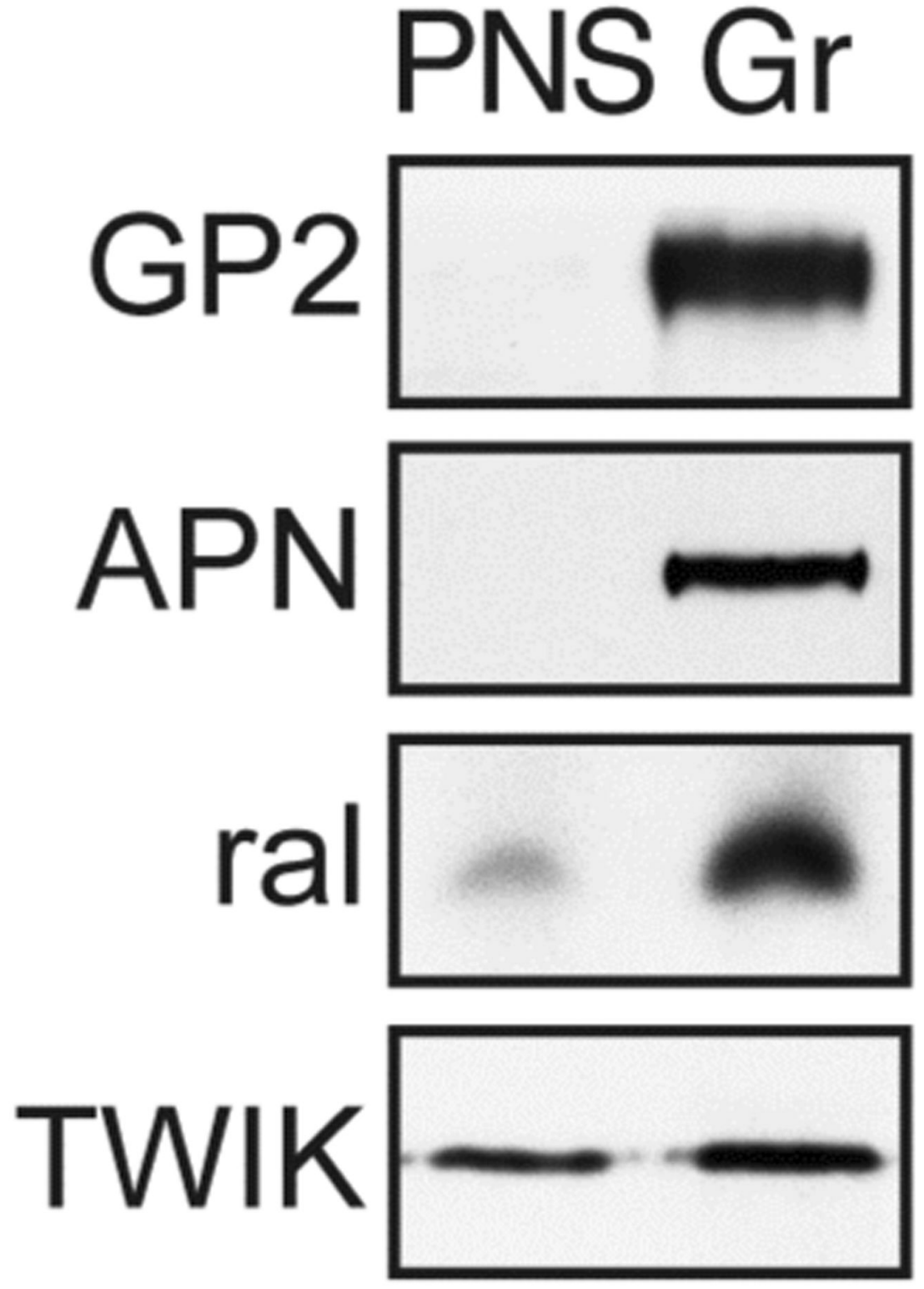

Figure 5.

Immunoblotting of purified zymogen granule fractions. Granules and their membranes were prepared from bovine pancreas (top 2 panels) or rat pancreas (bottom 2 panels). $3 \mu \mathrm{g}$ of membranes from the PNS or purified granules were subjected to SDS/PAGE and transferred to nitrocellulose. Immunoblotting was conducted using enhanced chemiluminescence and antibodies to GP2, aminopeptidase N, ral and TWIK-2/rKCNK6. All of these proteins were enriched in granule membranes $(\mathrm{Gr})$ as compared to total PNS membranes. 


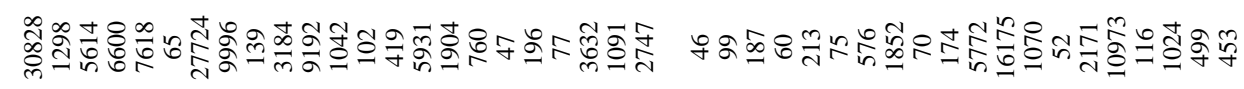

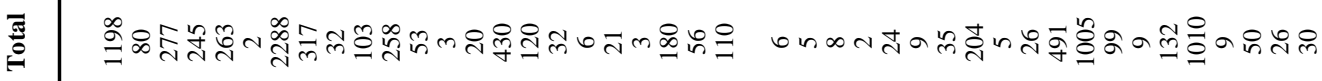

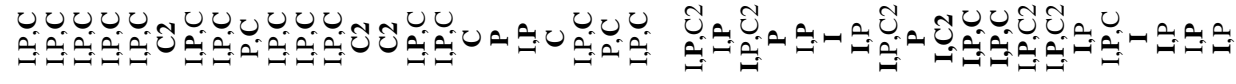

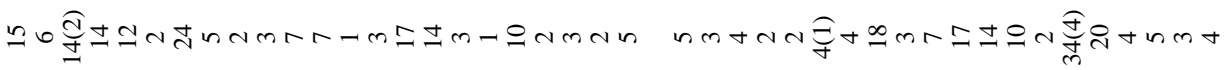

$\stackrel{\text { ॥ }}{\approx}$

요쇼요

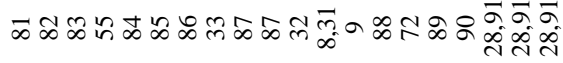

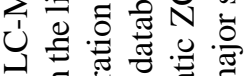

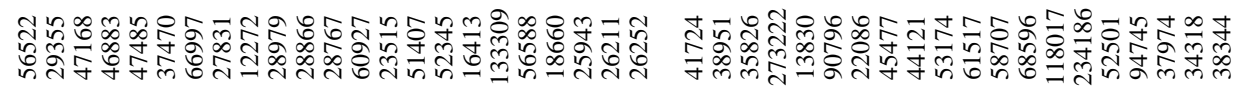
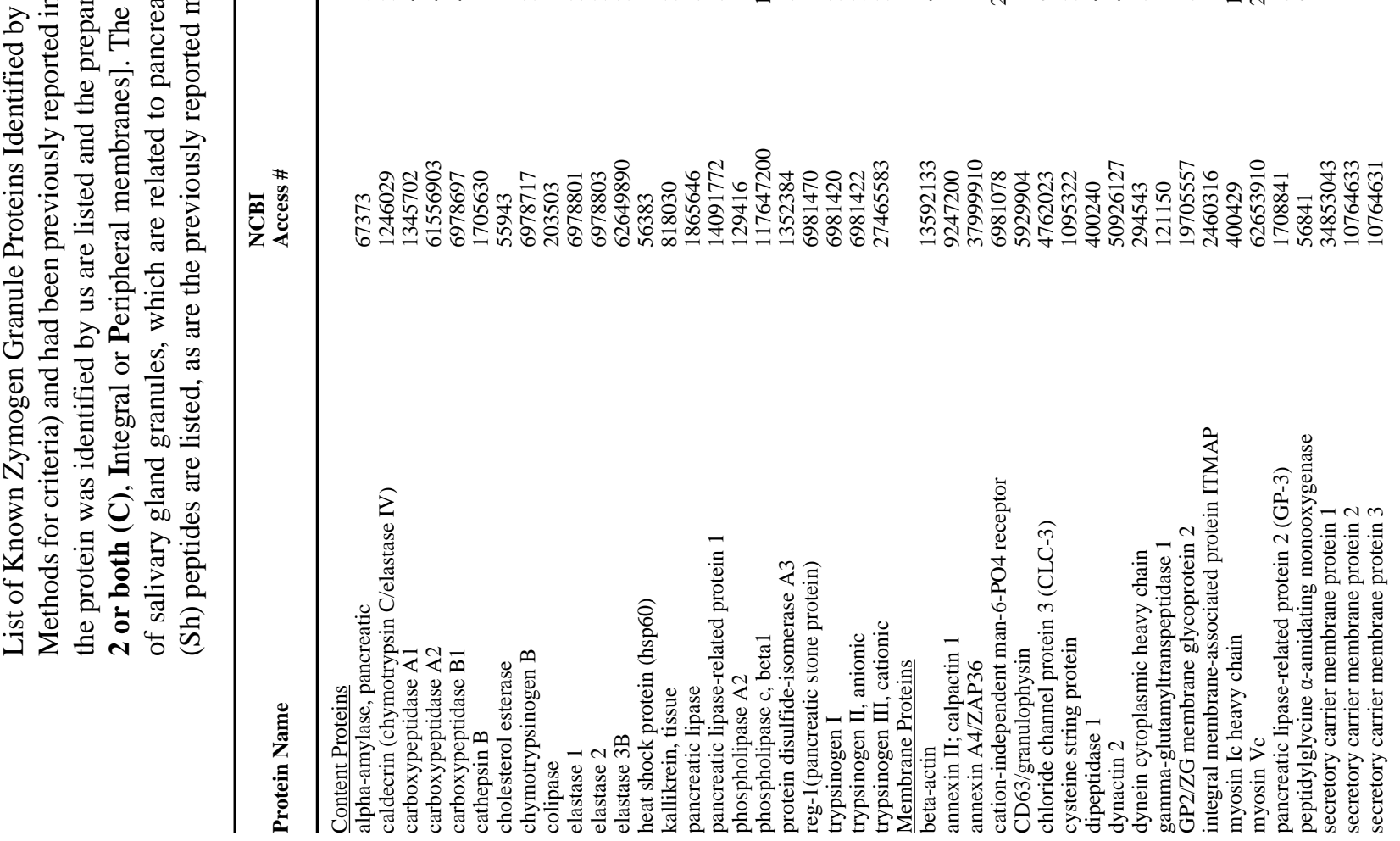


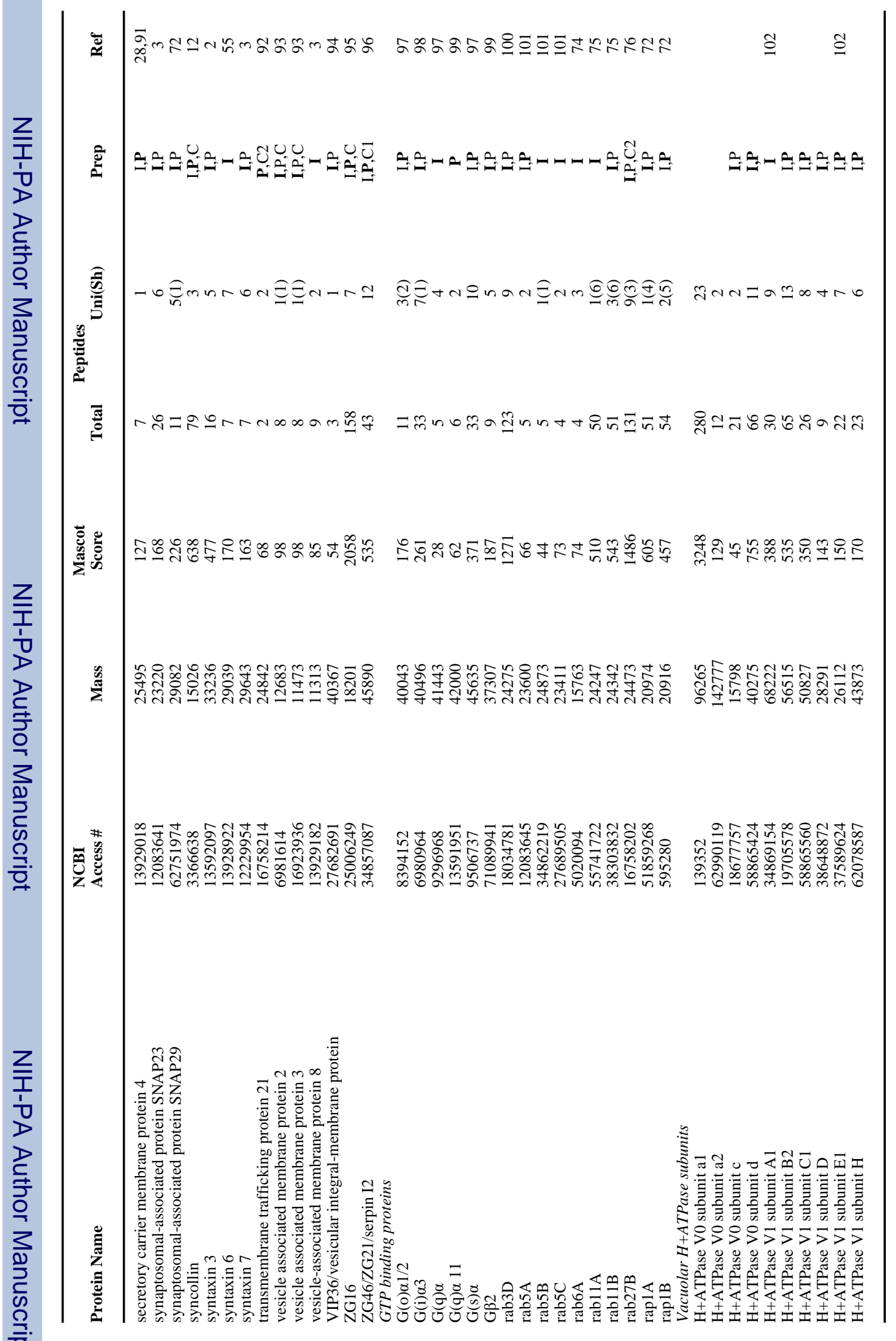

J Proteome Res. Author manuscript; available in PMC 2008 November 10. 


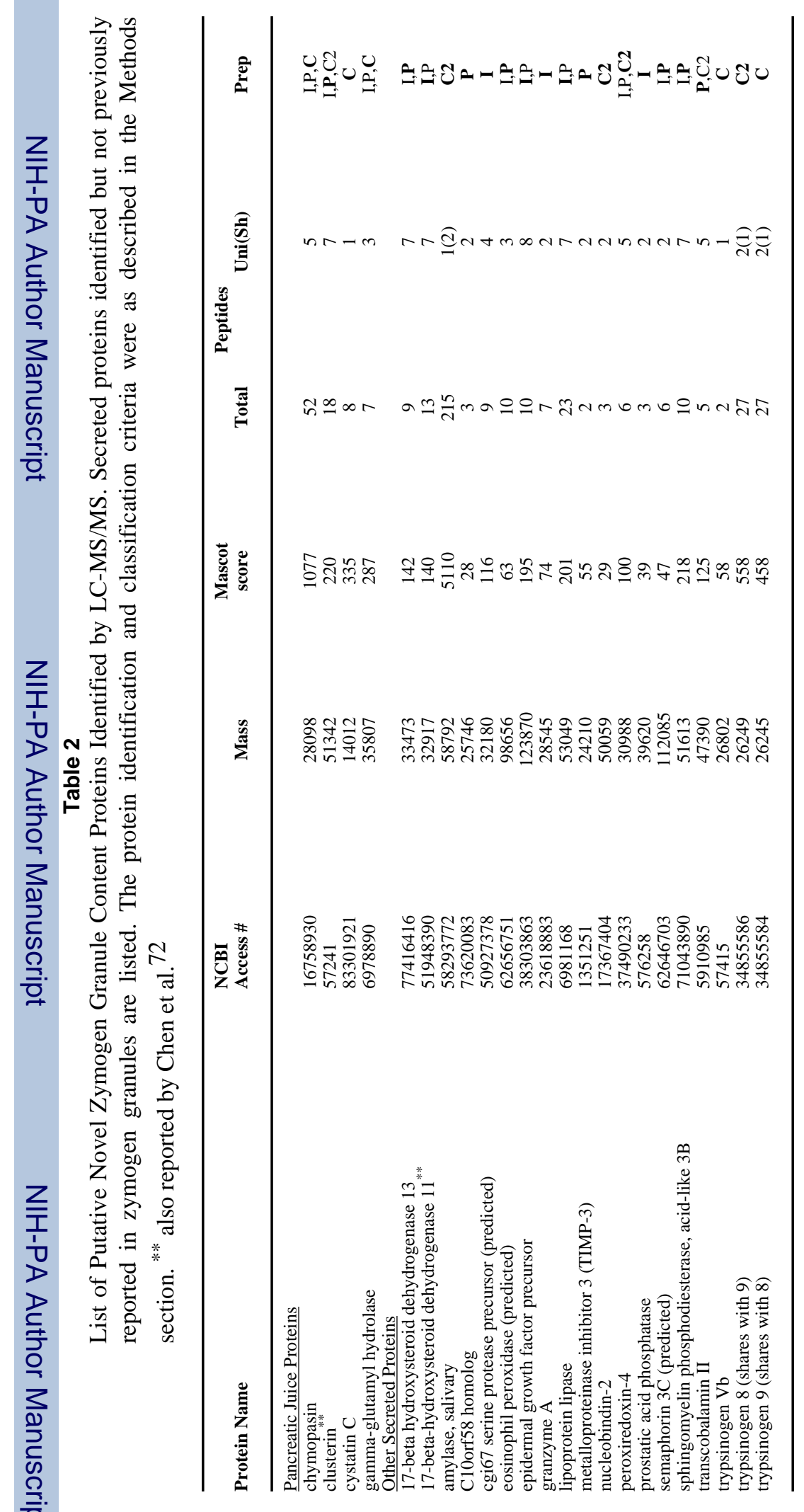

J Proteome Res. Author manuscript; available in PMC 2008 November 10. 


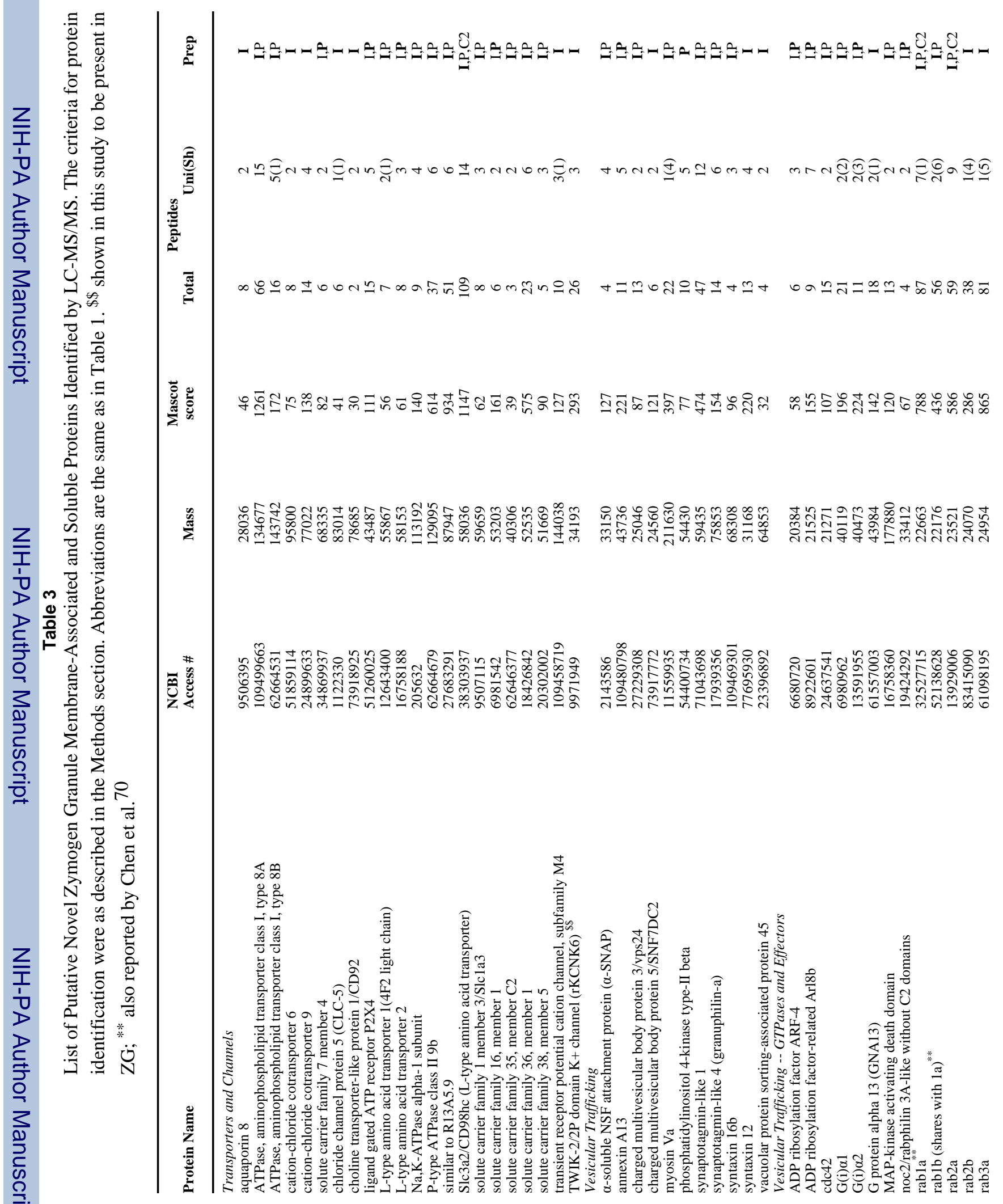




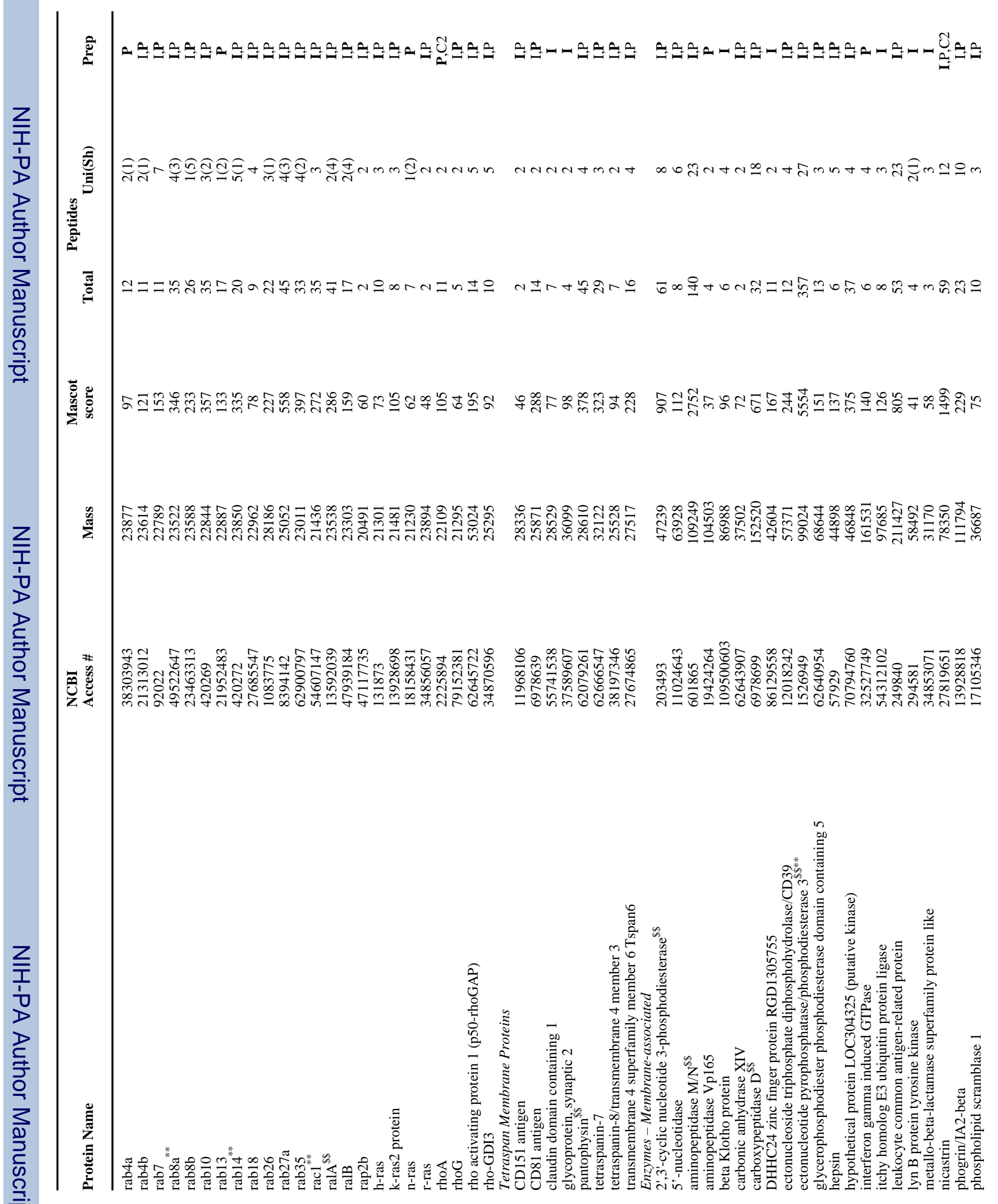




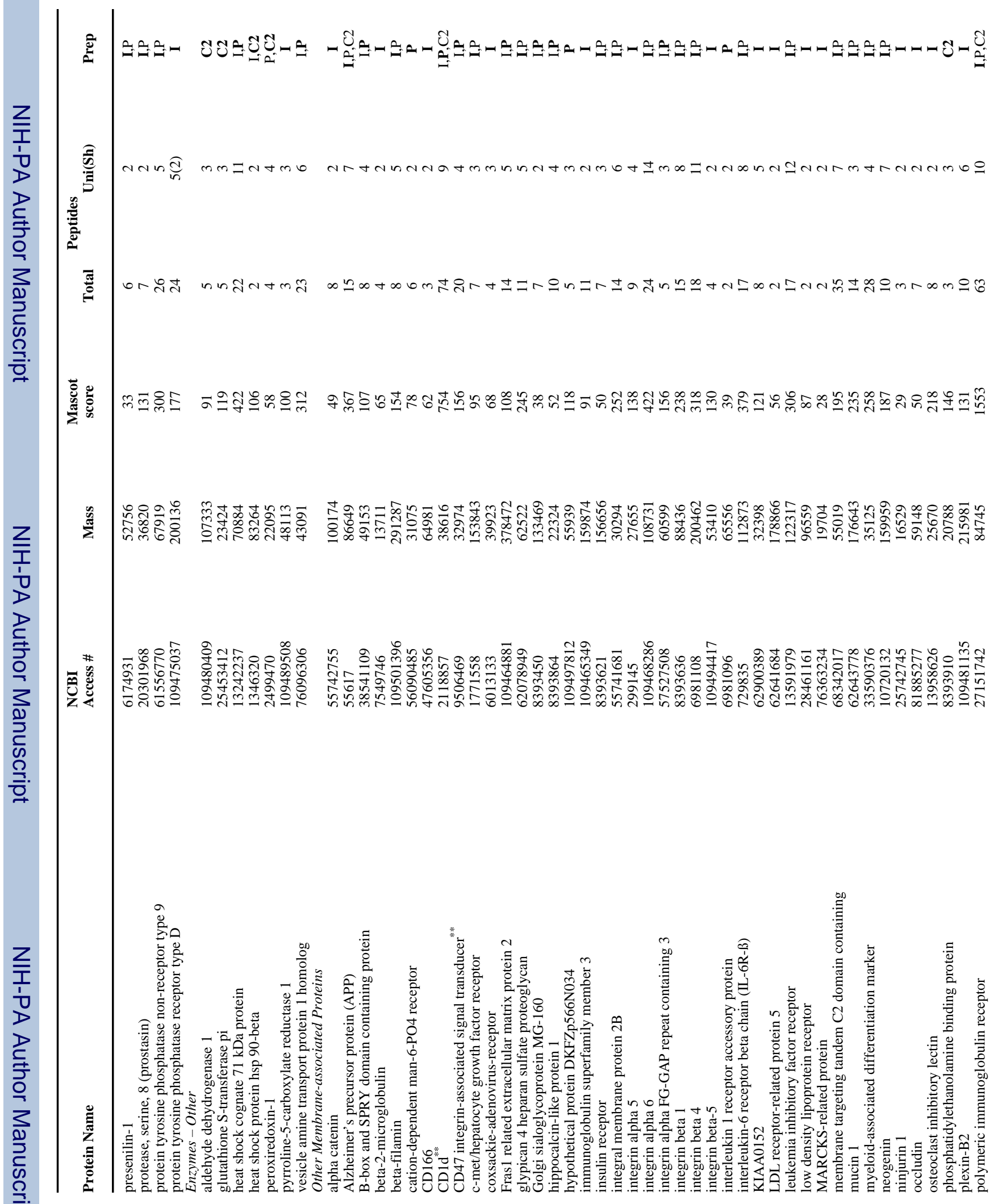




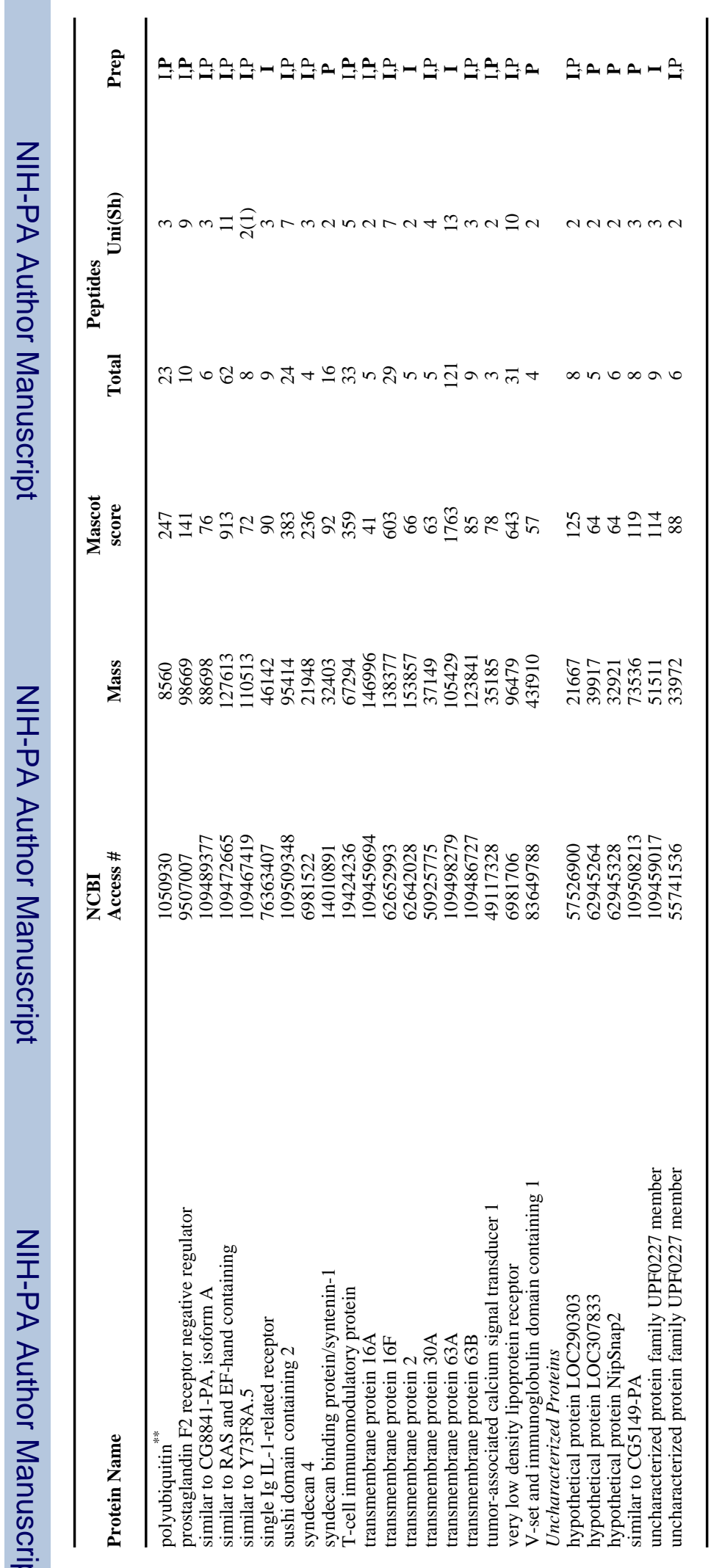

J Proteome Res. Author manuscript; available in PMC 2008 November 10. 